\title{
Groundwater origin and recharge in the hyperarid Cordillera de la Costa, Atacama Desert, northern Chile.
}

Christian Herrera ${ }^{1,2}$, Carolina Gamboa ${ }^{1,2}$, Emilio Custodio ${ }^{3}$, Teresa Jordan ${ }^{4}$, Linda Godfrey ${ }^{5}$, Jorge Jódar ${ }^{6}$, José A. Luque ${ }^{1,2}$, Jimmy Vargas ${ }^{7}$, Alberto Sáez ${ }^{8}$

${ }^{1}$ Departmento de Ciencias Geológicas, Universidad Católica del Norte, Antofagasta, Chile

${ }^{2}$ CEITSAZA-Research and Technological Center of Water in the Desert, Northern Catholic University, Antofagasta, Chile

${ }^{3}$ Groundwater Hydrology Group, Dept. Civil and Environmental Eng., Technical University of Catalonia (UPC). Royal Academy of Sciences of Spain

${ }^{4}$ Department of Earth \& Atmospheric Sciences and Atkinson Center for a Sustainable Future, Snee Hall, Cornell University, Ithaca, NY 14853-1504, USA

${ }^{5}$ Earth and Planetary Sciences, Rutgers University, 610 Taylor Road, Piscataway, NJ 08854, USA.

${ }^{6}$ Groundwater Hydrology Group, Dept. Civil and Environmental Eng., Technical University of Catalonia (UPC), Hydromodel Host S.L. and Aquageo Proyectos S.L., Spain

${ }^{7}$ Mining Company Los Pelambres, Av. Apoquindo 4001 Piso 18, Las Condes, Santiago, Chile

${ }^{8}$ Department of Earth and Ocean Dynamics, University of Barcelona, C. Martí i Franqués s/n, 08028 Barcelona, Spain

\section{GRAPHICAL ABSTRACT}

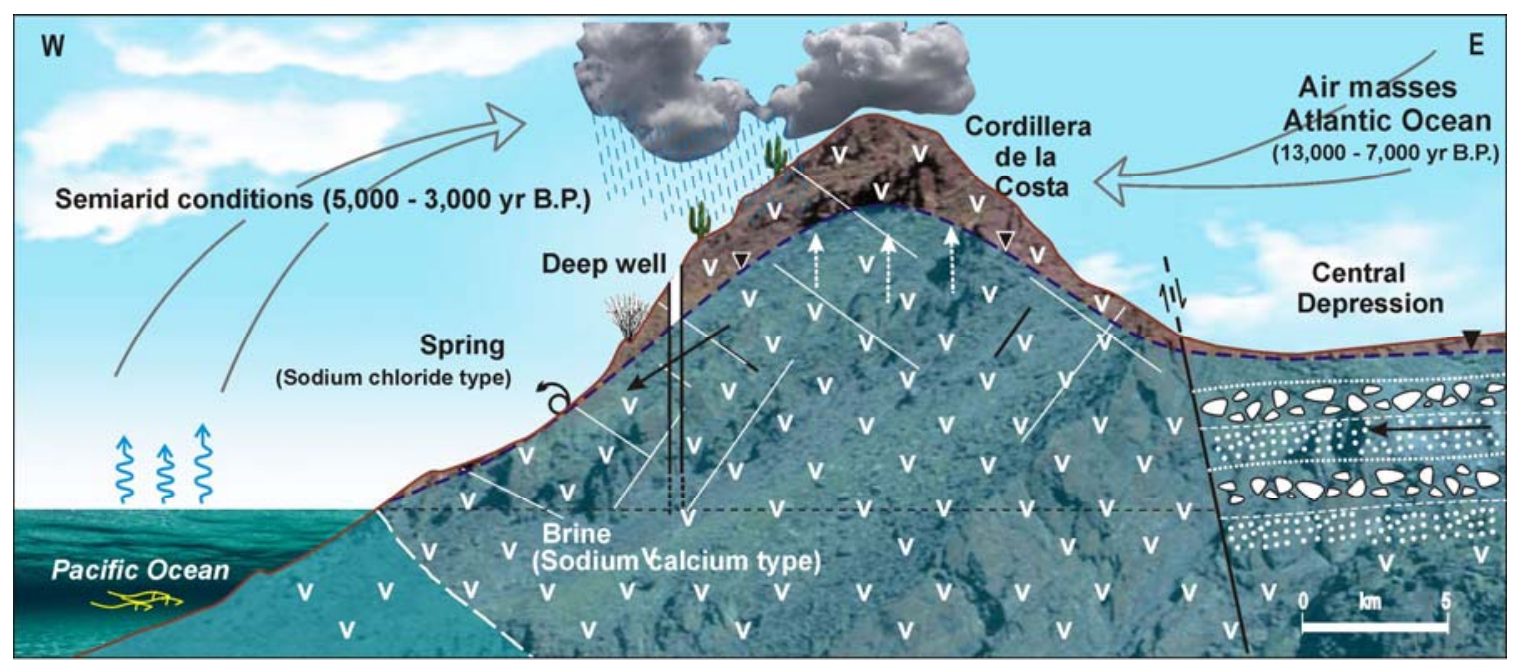




\title{
Highlights
}

-Small springs have been recognized in the hyper-arid coastal zone of the Atacama Desert

-The $\delta^{18} \mathrm{O}$ and $\delta^{2} \mathrm{H}$ values of spring waters are similar to coastal region rainfall

-The residence time of the waters from springs varies between 1 and 2 hyr, up to 5 hyr

-Waters from the deep wells are isotopically much heavier than those of springs

-Turnover time for deep waters varies between 7 and 13 hyr, which overlaps the CAPE events

\begin{abstract}
The Cordillera de la Costa is located along the coastline of northern Chile, in the hyperarid Atacama Desert area. Chemical and isotopic analyses of several small coastal springs and groundwater reservoirs between $22.5^{\circ} \mathrm{S}$ and $25.5^{\circ} \mathrm{S}$ allow understanding groundwater origin, renewal time and the probable timing of recharge. The aquifers are mostly in old volcanic rocks and alluvial deposits in small intra-mountain basins. All spring waters are brackish, of the sodium chloride type due to intensive concentration of precipitation due aridity and for deep groundwater to additional water-rock interaction in slowly renewed groundwater and mixing with deep seated brines. The heavy $\delta^{18} \mathrm{O}$ and $\delta^{2} \mathrm{H}$ values in spring water are explained by recharge by the arrival of moist air masses from the Pacific Ocean and the originally lighter values in the deep wells can be associated to past recharge by air masses coming from the Atlantic Ocean. Current recharge is assumed almost nil but it was significant in past wetter-than-present periods, increasing groundwater reserves, which are not yet exhausted. To explain the observed chloride content and radiocarbon $\left({ }^{14} \mathrm{C}\right)$ activity, a well-mixed (exponential) flow model has been considered for aquifer recharge. The average residence time of groundwater feeding the springs has been estimated between 1 and 2 hyr, up to 5 hyr and between 7 and 13 hyr for deep well water, assuming that current recharge is much less than during the previous wetter period. The recharge period feeding the coastal springs could have been produced 2 to 5 hyr BP, when the area was already inhabited, and recharge in the Michilla mine was produced during the 10 to 14.5 hyr BP CAPE (Central Andean Pluvial Event) pluvial events of the central Andes). Age uncertainty cannot be solved with only radiocarbon data. The approximate coincidence of turnover time with the past wet periods, as revealed by paleoclimate data, points to significant recharge during them.
\end{abstract}

\section{1.- INTRODUCTION}


Coastal aquifers in northern Chile provide a unique opportunity to understand climate variability in the currently hyper-arid Atacama Desert. The Atacama is one of the driest places on Earth (Hartley and Chong, 2002). The average long-term precipitation is less than $1 \mathrm{~mm} / \mathrm{yr}$ in some areas. Nevertheless, localized coastal storms can occur with a 15-20 year recurrence interval which may locally exceed $20 \mathrm{~mm}$ per event (Vargas et al., 2000). The large rare storms generate ephemeral surface runoff and small endorheic lagoons, which can produce concentrated recharge in certain areas of the Cordillera de la Costa.

The climate history during the Late Quaternary in northern Chile is complex. According to sedimentary records from various areas of the Atacama Desert, since the onset of hyper-arid conditions in the Middle Miocene the climate was characterized by an alternation of arid and less arid periods (Vargas et al., 2000; 2006; Rech et al., 2006; Jordan et al., 2014). Infrequent and highintensity storm events, with recurrence intervals of decades (e.g. the ENSO, El Niño-Southern Oscillation phenomena) or centuries (changes in solar and cosmic-ray activity or millennial orbital forcing), could enable significant recharge in brief periods of time. Recent storms have happened, such as that in March 2015 over coastal northern Chile (Jordan et al., 2015; Bozcurt et al., 2016; Wilcox et al., 2016), with catastrophic consequences for urban population, serve as examples. This storm was triggered in part by the 2015/2016 El Niño warm event and also affected a broad interior area. The March 2015 storm produced recharge in the southern Atacama Desert (Salas et al., 2016). Another major storm occurred in June 2017 (Jordan et al. 2018). During these two rare events, 20 and $21 \mathrm{~mm}$ of rain fell, respectively, in the coastal city of Antofagasta.

Given evidence from sedimentary and midden records for several "less dry" periods during the last $14.5 \mathrm{kyr}$, it is hypothesized that during some of these less-dry periods the increased frequency of high-intensity storm events led to the main recharge of aquifers in many parts of the Atacama. The moisture sources that fed the wetter-than-present periods of the interior regions are assumed to be the consequence of changes in summer NE and SE atmospheric regimes, which transport humidity from the Atlantic through the Amazonian basin (NE) and the Chaco region (SE) (Aravena et al., 1999). Higher groundwater levels expressed by high stands of lake levels in western Andean Miscanti and Lejía lakes at $23^{\circ}-24^{\circ} \mathrm{S}$ (Grosjean et al., 2003), by groundwater discharge deposits in the Precordillera at $24^{\circ}-26^{\circ} \mathrm{S}$ (Quade et al., 2008; Sáez et al., 2016), and by aggraded terraces in Sierra Moreno, in the eastern Atacama Desert around $21^{\circ} \mathrm{S}$ (Gayo et al., 2012), point to the existence of those enhanced eastern moisture sources.

Sources of moisture from Pacific Ocean to northern Chile have also been proposed. Herrera and Custodio (2014) presented evidence that the water from some small coastal springs near the city of Antofagasta originated from Pacific moisture and was probably recharged between 3 and $5 \mathrm{kyr}$ BP, as a consequence of ENSO forcing (EI Niño - Southern Oscillation). A Westerlies Pacific moisture source was also suggested by Grosjean et al. (1997) for the Negro Francisco Andean lake at the south end of the Atacama Desert $\left(27^{\circ} \mathrm{S}\right)$, during the last $5 \mathrm{kyr}$ -

Due to the scarcity of sedimentological and paleobotanical paleoclimate records at key latitudes along the coastal fringe of the Atacama Desert, doubts arise about the spatial and temporal variability of paleoclimate and its causes. To try to overcome this situation, groundwater chemistry 
and environmental isotopes could provide proxies to understand and determine the effects of paleoclimate events. To that end, the main objective of this investigation is to contribute to the understanding of the origin and timing of recharge of the water stored in aquifers in the Cordillera de la Costa by means of chemical and environmental stable and radioactive isotopes.

\section{2.- Cordillera de la Costa setting}

\section{Relief and climate}

The Cordillera de la Costa (Coastal Range) is an N-S oriented morpho-structural unit, $2000 \mathrm{~km}$ long, from $18^{\circ} \mathrm{S}$ to $38^{\circ} \mathrm{S}, 10-40 \mathrm{~km}$ wide, with an average elevation of $1000 \mathrm{~m}$ and topping at $2000 \mathrm{~m}$ (Fig. 1). In the considered area, the Cordillera de la Costa is bounded to the east by the Central Depression, which is filled by Cenozoic deposits (Sáez et al., 1999). The Cordillera de la Costa is a mountainous barrier to the westward flow toward the ocean of groundwater from the Precordillera and the wetter Altiplano areas. Most groundwater coming from the eastern highlands evaporates in the intermediate depressions, forming large salares (salt pans). This causes the groundwater east of the Atacama Fault (Fig. 2) to have a different composition than groundwater to the west of this important crustal feature.

The northern sector of the Cordillera de la Costa, between $18^{\circ} \mathrm{S}$ to $26^{\circ} \mathrm{S}$, is part of the hyper-arid Atacama Desert, which spans from the western foothills of the Andes to the coast. The hyperaridity is a consequence of three factors: a) the presence of the Cordillera de los Andes (Andes Range) and the Altiplano, which act as a high elevation physical barrier that blocks moisture from the Atlantic, b) the Humboldt ocean current, whose cold water hinders the production of Pacific moisture, causes an atmospheric inversion and also modulates the strength of the Pacific anticyclone (Garreaud et al., 2010), and c) the fact that the westerlies, which transport Pacific moisture to southern Chile, commonly produce precipitation only as far north as $30^{\circ} \mathrm{S}$ latitude (Sáez et al. 2016). The sector of the Cordillera de la Costa investigated here, between $22.5^{\circ} \mathrm{S}$ and $25.5^{\circ} \mathrm{S}$, receives average precipitation of less than $4 \mathrm{~mm} / \mathrm{yr}$ (DGA, 2009), most of it during the austral winter (Houston, 2006). However, in El Niño years, when the probability of extreme precipitation events associated with an increase of ocean surface temperature in the tropics increases, the rainfall may reach $10 \mathrm{~mm} / \mathrm{yr}$ along the coast (Garreaud, 2009).

Persistent fog (camanchaca) in the winter months is common on the ocean side of the Cordillera de la Costa. This is the consequence of low elevation stratocumulus clouds beneath a persistent temperature inversion (Cereceda et al., 2002; 2008a). The contribution of this fog to recharge in the considered area is probably nil, based on observations near Antofagasta. There, the cloud base is above land level, although some local contribution to recharge could be produced in higher areas, such as Cuncun, Panul, Perales and sites near Taltal. To the south of the area considered here, which is less arid and the fog more dense, the contribution does not exceed $10 \mathrm{~mm} / \mathrm{yr}$ (Roman, 1999). Isotopic studies of rainfall in central-northern Chile indicate that this type of drizzle does not produce significant recharge to aquifers, although it favors the development of vegetation (Aravena et al., 1989; Squeo et al., 2006). The fog rarely reaches the Central 
Depression, as the high ranges of the Cordillera de la Costa act as a barrier, except where there are wide canyons across it, like the Loa river valley (Rech et al., 2003; Cereceda et al., 2008b).

The temperature remains relatively stable during the year, with monthly average values ranging between $13.5^{\circ} \mathrm{C}$ and $20.1^{\circ} \mathrm{C}$ (DGA, 2009).

\section{Geological and hydrogeological setting}

The Cordillera de la Costa corresponds to the Upper Jurassic-lower Upper Cretaceous Volcanic arc related to subduction of the Nazca plate beneath South America (Fig. 2). The Jurassic-Cretaceous volcanic activity is mainly represented by La Negra Formation, which reaches up to $8 \mathrm{~km}$ in thickness (González and Niemeyer, 2005). The plutonic rocks located in the segment between $18^{\circ} \mathrm{S}$ and $25^{\circ} \mathrm{S}$ have a wide compositional range, from gabbros to granites (Scheuber and González, 1999). Basaltic, andesitic and dacitic dike swarms intrude these volcanic and plutonic rocks. The volcanic rocks are mainly andesitic and basaltic andesite rocks, with subordinate intercalations of continental and marine volcanoclastics (Charrier et al., 2007) and silica-rich pyroclastic rocks at the base. Most of the plutonic rocks and the dikes have calc-alkaline characteristics (Lucassen and Franz, 1994) and the small postmetamorphic gabbro plutons are tholeiitic. The scarce Paleozoic rocks are mainly composed of sediments and volcanics affected by low-grade metamorphism.

The Atacama Fault System is one of the most important structures of northern Chile. It is a regional strike-slip fault that can be traced for approximately $1000 \mathrm{~km}$ in a dominantly N-S direction, from $20^{\circ} \mathrm{S}$ to $30^{\circ} \mathrm{S}$ (González et al., 2006). A series of pull-apart basins are controlled by the Atacama Fault (Chong et al., 1999), which were filled by alluvial and saline sediments during the Oligocene-Miocene. These sediments unconformably overlie the Mesozoic rocks and are covered in unconformity by continental sediments of Plio-Quaternary age (Kay et al., 1989).

As a consequence, in the northern segment of the Cordillera de la Costa a number of fore-arc closed basins were formed during the Neogene. These basins are bounded and controlled by the Atacama fault system (Chong et al., 1999). The deposits filling these basins may contain evaporite deposits from old salares (salt pans), as illustrated by Salar Grande $\left(20.5^{\circ}-20.8^{\circ} \mathrm{S}\right)$, mainly composed of halite. The scarce presence of terrigenous material in Salar Grande halite may be an indication that the parental waters that fed the salares like these were groundwater (Warren, 2016).

The shallow crustal rocks in the Cordillera de la Costa have commonly very low hydraulic conductivity and transmissivity and are heterogeneous. This explains the existence of a high water table and perched aquifers that feed small permanent springs on the western flank of the Cordillera, despite the low recharge rate (Herrera and Custodio, 2014). Eight (8) groundwater samples from these springs were analyzed in the present study (Table 1). It can be expected that the upper volcanic formations constitute better and thicker aquifers than the intrusive rocks, in which permeability is mostly in the fractured and weathered upper part and close to major faults. On the other hand, small intra-mountain basins exist at the study area. They are filled with alluvial and eolian deposits from Miocene to Holocene age, which are associated with the Michilla and Ivan areas. From these mine areas twenty-one (21) samples were also collected for the present 
study (Table 2). Two tentative hydrogeological cross sections are shown in Fig. 3. The coastal springs of La Chimba and Los Perales are groundwater discharge sites, probably related to the regional water table. Other springs may result from perched aquifers when there is some current recharge. Beyond these concentrated visible outflows, diffuse discharge and outflow through small springs that fully evaporate can be expected. Cross-sections perpendicular to the coast help in understanding the hydrological processes, even though they are only a crude approximation (Fig. 3). Realistic groundwater flow also has an along-the-coast component governed by the spatial complexity of hydrogeological and topographical features.

\section{Hydrological relation between the Cordillera de la Costa and the Central Depression}

From the regional characteristics of northern Chile, there are two possible origins of the Cordillera de la Costa groundwater: 1) meteoric recharge in the Cordillera de la Costa, and 2) groundwater flow coming from the Central Depression as part of continuous regional flow from the Altiplano toward the ocean.

The small but significant current recharge in the relatively wetter mountainous regions of the Altiplano produces lateral mountain-front groundwater flow to the Central Depression (Magaritz et al., 1990; Leybourne and Cameron, 2006). For most of the Atacama Desert, this groundwater flow is stopped by the low permeability barrier created by the Cordillera de la Costa. At the latitudes of the study, the Central Depression is a large groundwater reservoir whose ultimate discharge is by evaporation. Groundwater shows up at the surface as crypto-wetlands and salt deposits, at elevations ranging between 500 and $1000 \mathrm{~m}$. This is the case of Salar del Carmen (1000 $\mathrm{m}$ asl), directly to the east of the city of Antofagasta, where the water table is only a few meters beneath the surface and salts precipitate from evaporating water brought to the surface by capillary action.

Potential hydrological connections between the Central Depression and the Cordillera de la Costa are impeded by very low permeability and high elevations of the Cordillera de la Costa rocks. Exceptions of rocks with greater permeability exist locally as small intra-mountain tectonic basins.. It is assumed that flow of groundwater ifrom the Central Depression to the coast through the Cordillera de la Costa will occur only where the range is crossed by important faults, whose fractured rocks are now more permeable and some have been eroded into important canyons. This is the case of the Loa River, to the north of the area being considered, and of La Negra brook to the south of Antofagasta city, which is linked to Las Vertientes spring.

\section{Paleoclimate history of the Atacama Region}

Multiple paleoclimate reconstructions of pluvial phases over millennial scales since the Last Glacial Maximum (LGM) show that the Atacama Desert was wetter than present during the last glacialinterglacial transition, although there are spatial variations in the timing and duration of these wetter intervals (Placzek et al. 2009, Herrera and Custodio, 2014; Sáez et al. 2016). Within the continental interior, the sedimentary and midden records have identified and established the chronology of two major regional pluvial (less arid) stages during the latest Pleistocene, often termed the "Central Andean (Atacama) Pluvial Event" or CAPE (Latorre et al., 2006): CAPE I (17.5- 
14.2 kyr BP) and CAPE II (13.8-9.7 kyr BP) (Quade et al., 2008; Placzek et al., 2009). CAPE I has been recognized in the organic-rich layers formed in shallow paleo-wetlands in the Domeyko Range (Quade et al., 2008; Sáez et al. 2016) and in the eastern boundary of the Salar de Atacama (Rech et al., 2002), as well as in the aggraded terraces west of the Andean foothills (Fig. 1, Sierra Moreno) (Nester et al., 2007; Gayo et al., 2012a; Gayo et al., 2012b). CAPE II was recognized, with less precise age bounds, as high stand levels in Miscanti and Lejía lakes at $23^{\circ}-24^{\circ} \mathrm{S}$ (Grosjean et al., 2003), in the western part of the Andes. In addition, CAPE II was also recognized in vegetated terraces west of Sierra Moreno, around $21^{\circ} \mathrm{S}$ (Nester et al., 2007; Gayo et al., 2012a) and in mineral deposits produced by groundwater discharge in the eastern Atacama Desert at $24^{\circ}-26^{\circ} \mathrm{S}$ (Quade et al. 2008, Sáez et al., 2016). Finally, there were one or more wet periods between the mid Holocene and the present, associated with strong ENSO episodes. The high variability of the strength of ENSO events caused precipitation to fluctuate widely during the past $5 \mathrm{kyr}$ (Grosjean et al. 2001; Latorre et al., 2002; Latorre et al. 2006; Latorre et al., 2013, Herrera and Custodio, 2014; Saéz et al., 2016).

On the coastal side of Antofagasta Region, the best available information about rainfall periods during the Pleistocene-Holocene corresponds to stratigraphic and chrono-stratigraphic studies conducted in alluvial fans. Radiocarbon $\left({ }^{14} \mathrm{C}\right)$ dating of seashells located at the base of a sequence of debris flows above eolian deposits shows that the end of a severe Holocene drought, the "Holocene Great Drought", occurred about 5.4 kyr BP (Vargas et al., 2006). The correlation of the eolian deposits located at the base of these alluvial deposits with the eolian deposits found in the archaeological site Chimba-13, in Quebrada Las Conchas $\left(23.3^{\circ} \mathrm{S}\right)$, bounds the period of drought to between 10 and $5.5 \mathrm{kyr} \mathrm{BP}$. Cosmic ray ${ }^{10} \mathrm{Be}$ generation on the skin of quartz clasts exposed on the surface of alluvial fans hung by faults in the northern part of the Mejillones Peninsula, shows that the last time water flowed in these alluvial fans occurred approximately $14 \mathrm{kyr}$ BP (Cortés et al., 2012). Therefore, the period of great drought in coastal northern Chile probably spanned between 14 and 5.4 kyr ago, followed by a less arid Late Holocene period. The trend seems to be toward the current drier conditions.

The study conducted by Herrera and Custodio (2014) concluded that there were wetter conditions between 5,000 and 3,000 years ago in the Cordillera de la Costa, which favored water recharge to the coastal aquifers. The wetter conditions were attributed to the incursion of warmer currents from the coast of Ecuador to northern Chile associated with a southward displacement of El NiñoSouthern Oscillation. The addition of data for deep well water, presented herein, underpins a more integrated and complete interpretation of the source of groundwater in Cordillera de la Costa, and therefore raises new questions about paleoclimate controls on recharge.

\section{Springs in the Cordillera de la Costa}

Groundwater in the hyperarid Cordillera de la Costa has been evaluated in the present study in order to determine the origin and recharge processes of groundwater resources. For this, two types of waters are evaluated: coastal spring waters ( 8 samples shown in Table 1 ) and groundwater of deep wells from intra-mountain basins (21 samples shown in Table 2). In addition 
to data from the coastal springs published previously (Herrera and Custodio, 2014), new data for Las Conchas and Taltal springs are added. The remaining chemical and isotopic data have not been published before (Table 1 and 2). This integrated data set better illuminates the hydrological complexity of the study area. The new hydrological information, especially for deep groundwater in Cordillera de la Costa, allows a more integrated and complete interpretation of the residence time of water resources and the complex relationships between them. Therefore, more accurate climatic interpretation can be elucidated.

The 8 springs considered and analyzed are located between $22.5^{\circ}$ and $25.5^{\circ} \mathrm{S}$. They yield small flows, between 7 and $19 \mathrm{~m}^{3} /$ day (Herrera and Custodio, 2014) (Fig. 1). These coastal springs do not receive groundwater flow from inland areas, except Las Vertientes spring. Las Vertientes spring is located at the mouth of the ravine of La Negra canyon, which discharges groundwater originating in the Central Depression. The physical characteristics of each one of these springs are presented in Table 1, including the rock types that dominate in the assumed recharge area. They are permanent springs, as shown by the numerous archaeological sites located in their vicinity (Núñez and Varela, 1968).

Table 1 Name, location and main characteristics of coastal springs.

\begin{tabular}{|c|c|c|c|c|c|c|c|}
\hline \multirow{2}{*}{$\begin{array}{l}\text { Spring } \\
\text { name }\end{array}$} & $\mathbf{N}$ & E & \multirow{2}{*}{$\begin{array}{c}\text { Elevation } \\
\text { (m asl) }\end{array}$} & \multirow{2}{*}{$\begin{array}{l}\text { Distance to } \\
\text { the shore } \\
\text { (m) }\end{array}$} & \multirow{2}{*}{$\begin{array}{l}\text { Discharge } \\
\left(\mathrm{m}^{3} / \text { day) }\right.\end{array}$} & \multirow{2}{*}{$\begin{array}{l}\text { Lithology of } \\
\text { saturated unit }\end{array}$} & \multirow{2}{*}{ Data source } \\
\hline & (UTM) & (UTM) & & & & & \\
\hline $\begin{array}{l}\text { Morro } \\
\text { Moreno }\end{array}$ & 7398012 & 338621 & 22 & 12 & 7 & $\begin{array}{l}\text { Aluvial sediments } \\
\text { and gabbro }\end{array}$ & \multirow{6}{*}{$\begin{array}{l}\text { Herrera \& Custodio } \\
\text { (2014) }\end{array}$} \\
\hline La Chimba & 7396287 & 361268 & 450 & 3700 & 19 & Andesite & \\
\hline Las Vertientes & 7378137 & 357724 & 154 & 1000 & 216 & Undifferentiated & \\
\hline Cuncun & 7281691 & 341980 & 12 & 20 & 13 & Granodiorite & \\
\hline Panul & 7258933 & 345728 & 370 & 2800 & 14 & Granodiorite & \\
\hline Los Perales & 7231045 & 353426 & 389 & 2000 & 19 & Diorite & \\
\hline Las Conchas & 7200443 & 353838 & 8 & 20 & 6 & Alluvial sediments & \\
\hline Taltal & 7189165 & 354242 & 217 & 2520 & 15 & Diorite & This study \\
\hline
\end{tabular}

\section{Groundwater in boreholes in the Michilla and Ivan mine areas}

Several groundwater sampling points were accessible in two mining areas in the highlands of the Cordillera de la Costa. They are located in small intra-mountain basins which are filled with alluvial and eolian deposits (Miocene-Holocene). They may contain salt deposits and brines. Table 2 shows the location and geology of each well. 
The Michilla mine is located to the north of the city of Antofagasta (Fig. 1 and 2). It is an underground mine excavated at the bottom of an open pit that currently reaches more than 500 $m$ deep. As mining operations deepened, some groundwater outflows were found (Vargas, 2018). At the bottom of the mine galleries, seven exploratory boreholes were drilled, with depths ranging between 150 and $400 \mathrm{~m}$ ( 25 to $-150 \mathrm{~m}$ asl) (Vargas, 2018). Four groundwater samples were obtained from these flowing wells and a further one from a fracture in the volcanic rock in one of the mine galleries. They correspond to a water table approximately $500 \mathrm{~m}$ deep (360 $\mathrm{m}$ asl) at that site, which is depressed by mine drainage. Groundwater is in volcanic and intrusive rocks. A hydrogeological cross section (Fig. 4) shows a series of geological faults in the area (Acevedo et al., 1997).

The Ivan mine is in a basin filled with alluvial and eolian sand deposits, to the north of Antofagasta city (Figures 1 and 2). Groundwater exploration was carried out in the basin to supply mine needs, but operation was cancelled due to the high salinity of pumped water (Montgomery and Associates, 1990). The water table in the sedimentary basin is $430 \mathrm{~m}$ asl, about $50 \mathrm{~m}$ below the local ground surface. The depth of the boreholes varies between 100 and $200 \mathrm{~m}$. A total of twelve chemical analyses were made on water samples from the wells drilled in the detrital sediments and one from a well inside one of the galleries of the mine.

Table 2.- Location and main characteristics of deep wells in the Cordillera de la Costa

\begin{tabular}{|c|c|c|c|c|c|c|}
\hline \multirow{2}{*}{ Sector } & \multirow{2}{*}{ Sample ID } & \multirow{2}{*}{ Type } & \multicolumn{2}{|c|}{ Coordinates (UTM) } & \multirow{2}{*}{$\begin{array}{l}\text { Lithology of } \\
\text { saturated unit }\end{array}$} & \multirow{2}{*}{ Data source } \\
\hline & & & $\mathrm{N}$ & $\mathrm{E}$ & & \\
\hline \multirow{7}{*}{ Michilla Mine } & M1 & Borehole inside the mine & 7491427 & 379227 & Andesite and diorite & \multirow{7}{*}{ this study } \\
\hline & M2 & Borehole inside the mine & 7491427 & 379227 & Andesite and diorite & \\
\hline & M3 & Fracture inside the mine & 7491427 & 379227 & Andesite and diorite & \\
\hline & M4 & Borehole inside the mine & 7491427 & 379227 & Andesite and diorite & \\
\hline & M6 & Borehole inside the mine & 7491427 & 379227 & Andesite and diorite & \\
\hline & M7 & Borehole inside the mine & 7491427 & 379227 & Andesite and diorite & \\
\hline & M8 & Borehole inside the mine & 7491427 & 379227 & Andesite and diorite & \\
\hline \multirow{13}{*}{ Ivan Mine area } & WW-24 & Borehole outside the mine & 7415955 & 358538 & Detritic sediments & \multirow{13}{*}{$\begin{array}{c}\text { Montgomery \& } \\
\text { Associates (1990) }\end{array}$} \\
\hline & DPB-B & Borehole outside the mine & 7415228 & 358635 & Detritic sediments & \\
\hline & WW-13 & Borehole outside the mine & 7415854 & 362643 & Detritic sediments & \\
\hline & WW-3 & Borehole outside the mine & 7415723 & 359025 & Detritic sediments & \\
\hline & WW-3A & Borehole outside the mine & 7415718 & 358996 & Detritic sediments & \\
\hline & WW-8 & Borehole outside the mine & 7415228 & 358736 & Detritic sediments & \\
\hline & WW-10 & Borehole outside the mine & 7415228 & 359629 & Detritic sediments & \\
\hline & WW-16 & Borehole outside the mine & 7415146 & 358105 & Detritic sediments & \\
\hline & WW-19 & Borehole outside the mine & 7415677 & 362955 & Detritic sediments & \\
\hline & WW-20 & Borehole outside the mine & 7415460 & 363859 & Detritic sediments & \\
\hline & DPW-A & Borehole outside the mine & 7415654 & 363050 & Detritic sediments & \\
\hline & DPW-C & Borehole outside the mine & 7415689 & 362931 & Detritic sediments & \\
\hline & Ivan mine & Borehole inside the mine & 7417251 & 369891 & Intrusive rock & \\
\hline
\end{tabular}




\section{Timing of aquifer recharge: general considerations}

In most cases, sampled groundwater cannot be assumed to have been a portion of water moving unaltered from the point of recharge to the point where it is sampled. Instead, the sample is a mixture of waters with a wide range of transit times through the unsaturated and saturated zones. Consequently, the resulting corrected carbon isotope content does not represent an age, except for the special case of pure piston flow under constant recharge conditions. When the appropriate mixing model is adopted, the ${ }^{14} \mathrm{C}$ corrected content can be converted into average renewal (turnover, renovation) time of water in the system, which includes the saturated zone (aquifer system) and the unsaturated zone. This conversion needs a validated conceptual groundwater flow model (Zuber, 1986; Jódar et al., 2014). This also applies to perched aquifers and the associated recharge and water reserves, when the hydrological conditions are known.

For a well-mixed (exponential) reservoir containing a water depth $\mathrm{H}$ and receiving a spatially and temporally uniform recharge $R$ with $C_{R}$ radioactive tracer concentration, the concentration of the outflow $C$, for a decay constant $\lambda$, can be deduced from a simple balance. The well-known result (see Custodio and Jódar, 2016 for explanation and references) is

$C_{R} / C=1+\lambda H / R$.

Thus, the ${ }^{14} \mathrm{C}$ activity depends on $\mathrm{H} / \mathrm{R}$, which is the average groundwater turnover time of water in the aquifer, $\tau$. The conditions of validity are negligible unsaturated zone thickness effect, constant recharge in space and time and a homogeneous aquifer. This is the exponential flow model. Water mixing is not produced inside the system but in the outflow, as in a spring discharging the full aquifer thickness or by pumping a fully penetrating, long-screened well. It can be easily demonstrated that the results from an exponential flow model coincide with those of a well-mixed reservoir when the saturated thickness is constant (Custodio and Jódar, 2016).

Climate fluctuations producing significant changes in recharge rate are not accompanied by significant variation in the concentration of radiocarbon in recharging water. Therefore, recharge changes do not translate into a clear modification in ${ }^{14} \mathrm{C}$ activity. It can be shown (Custodio and Custodio-Ayala, 2014; Custodio et al., 2018) that in an exponential flow aquifer, the observed changes in recharge over all the surface area are mostly due to variations of water reserves (water depth) and the unsaturated zone thickness. These changes may last a long time in aquifers with slow renewal rate. Consequently, ${ }^{14} \mathrm{C}$ is not a useful tool to define the timing of recharge due to wetter periods in the past, although results should be compatible with what is expected by applying other techniques. The ${ }^{14} \mathrm{C}$ activity depends mostly on the ratio of water reserve to recharge.

\section{3.- METHODOLOGY}

Previous investigation at the Cordillera de la Costa was conducted by Herrera and Custodio (2014). Seven (7) groundwater samples from coastal springs were collected and analyzed for major ions and isotopic composition $\left(\delta^{18} \mathrm{O}, \delta^{2} \mathrm{H},{ }^{3} \mathrm{H}, \delta^{34} \mathrm{~S}, \delta^{13} \mathrm{C}\right.$ and $\left.{ }^{14} \mathrm{C}\right)$. These preliminary samples were 
collected in June 2005 and July 2006 (Table 1). Herein additional chemical analyses are presented, which provide a new and more complete data set that covers the spatial and temporal variation in the chemical and isotopic signal of groundwater. These new data are related to: a) a new campaign of spring sampling conducted in April 2014 (included in Table 1), b) analytical data from deep well groundwater samples contained in an unpublished technical report of Montgomery and Associates (1990) for the Ivan mine area (included in Table 2), and c) analytical data for groundwater from the Michilla mine (included in Table 2) provided by coauthor Vargas. The sources of data are described as notes in Tables 1 and 2. Finally, two samples of rainfall obtained in Antofagasta city in the very rare, large rainfall storm in March 2015, were also analyzed for $\delta^{18} \mathrm{O}$ and $\delta^{2} H$ (Table 5)

The springs of the coastal side of Antofagasta Region were sampled directly from the fractures through which water outflows (samples from Table 1). The flowing boreholes inside the Michilla mine were sampled directly (Vargas, 2018; samples included in Table 2). The well inside the Ivan mine was sampled with a bailer (Montgomery and Associates, 1990). Sampling and analysis conditions of the other points in Ivan mine are not reported in the report of Montgomery and Associates (1990).

The comments on sampling given below only refer to samples taken during the mentioned field campaigns (June 2005, July 2006 and April 2014). The same analytical procedure was conducted for samples presented in Herrera and Custodio (2014), in Vargas (2018), and for the new springs samples collected at Las Conchas and Taltal. Water temperature, $\mathrm{pH}$, electrical conductivity, and other chemical determinations (such as redox conditions and dissolved oxygen) were performed in the field. Eleven samples were collected for total dissolved inorganic carbon (TDIC) and ${ }^{14} \mathrm{C}$ measurement. Seven of these samples are from springs (Herrera and Custodio, 2014), three from deep boreholes and one from a fracture in the Michilla mine gallery fum vargas, 2018).

Water samples for chemical analysis were immediately filtered in the field using $0.45 \mathrm{~mm}$ Milipore MF filters and stored in $1000 \mathrm{~mL}$ double-stoppered polyethylene bottles, without air bubbles and protected from light. The water samples for $\delta^{18} \mathrm{O}$ and $\delta^{2} \mathrm{H}$ analysis were stored in $50 \mathrm{~mL}$ polyethylene bottles. Water samples were labeled and immediately stored in a freezer. They were sent to the different laboratories as soon as possible to avoid storage problems.

The new chemical analyses of major water constituents were made at the Water and Industrial Liquid Waste Area Analysis of DICTUC, Santiago (Chile). Anions were determined by absorption spectrophotometry $\left(\mathrm{Cl}, \mathrm{SO}_{4}, \mathrm{NO}_{3}\right)$ and titration $\left(\mathrm{HCO}_{3}\right)$, and cations by atomic absorption and plasma emission spectrometry. $\mathrm{SiO}_{2}$ content was determined by molecular absorption photometry. Ion balances were examined for each groundwater sample as a quality-assurance check of the chemical analyses. Determinations of bromide and chloride have also been made on a limited number of samples at the IGME laboratory, Madrid, by high performance anion chromatography. 
The $\delta^{18} \mathrm{O}$ and $\delta^{2} \mathrm{H}$ analyses were performed at the Environmental Isotope Laboratory of the Chilean Nuclear Energy Commission (CCHEN) and referred to the V-SMOW standard for $\delta^{18} \mathrm{O}$ and $\delta^{2} \mathrm{H}$. The analytical accuracy is better than $0.2 \%$ for $\delta^{18} \mathrm{O}$ and $2 \%$ or for $\delta^{2} \mathrm{H}$. Radiocarbon $\left({ }^{14} \mathrm{C}\right)$ activities (and also the $\delta^{13} \mathrm{C}$ content) were measured by accelerator mass spectrometry (AMS) at Beta Analytic Laboratory, United States. The ${ }^{14} \mathrm{C}$ activities were expressed as percent modern carbon (pmC), with standard deviations ranging from 0.1 to $0.3 \mathrm{pmC}$. The values of $\delta^{13} \mathrm{C}$ are reported relative to the V-PDB standard and their accuracy is better than $0.2 \%$.

\section{4.- RESULTS}

\section{Chemical results}

Table 3 shows the new analytical results from the deep wells (Michilla and Ivan mine areas) and the coastal springs. According to Herrera and Custodio (2014), the coastal spring waters are brackish to saline, with electrical conductivity between 2 and $25 \mathrm{mS} / \mathrm{cm}$ and temperature between 13.5 and $23.0{ }^{\circ} \mathrm{C}$. They are of the sodium chloride type, with calcium being the second most abundant cation. This is also applicable to the two new coastal springs of Las Conchas and Taltal. For the case of the new deep groundwater data, all waters from deep wells are saline, with electrical conductivity ranging between 24 and $72 \mathrm{mS} / \mathrm{cm}$ and temperature between 25 and $29^{\circ} \mathrm{C}$. They are of the sodium chloride and calcium chloride types. The ion balance error of most analyses is less than $6 \%$. Data with suspected accuracy issues have been discarded, especially those for some minor ions reported in the Ivan mine study.

The modified Stiff diagrams of water for the sampling points (Fig. 5) show the marked salinity differences between spring and the deep well waters. The less saline waters are located in the westernmost side of the Cordillera de la Costa.

Total dissolved inorganic carbon (TDIC) content in water is the sum of dissolved $\mathrm{CO}_{2}, \mathrm{H}_{2} \mathrm{CO}_{3}, \mathrm{HCO}_{3}^{-}$ and $\mathrm{CO}_{3}{ }^{2-}$. As almost all waters in the considered area have a pH between 7.2 and 8.0, the TDIC is close to the $\mathrm{HCO}_{3}$ content. Values down to $10 \mathrm{mg} / \mathrm{L}$ are found in Michilla wells and Cuncun spring. Other springs have TDIC values close to $100 \mathrm{mg} / \mathrm{L}$. High $\mathrm{HCO}_{3}$ values are found in Los Perales spring $(180 \mathrm{mg} / \mathrm{L})$ and especially in Las Conchas spring $(550 \mathrm{mg} / \mathrm{L})$.

The $\mathrm{rNa} / \mathrm{rCl}$ ratio ( $\mathrm{r}$ means that the concentration is in meq/L) of the spring water is similar to or lower than that of sea water $(\mathrm{rNa} / \mathrm{rCl}$ for sea water $=0.85)$. In the Ivan mine water, the ratio is consistently less than that of sea water and there is no clear trend between this ratio and salinity (Fig. 6a). The samples from the Michilla deep wells have very low ratios.

The $\mathrm{rSO}_{4} / \mathrm{rCl}$ ratio of spring waters is somewhat higher than that of seawater $(0.12)$ and tends towards the marine value as salinity increases (Fig. 6b). For deep well water, the $\mathrm{rSO}_{4} / \mathrm{rCl}$ ratio is lower than sea water and decreases as salinity increases.

The $\mathrm{rCl} / \mathrm{rBr}$ ratio is in the range of 680 to 820 for spring water and tends to that of sea water (655) 
as salinity decreases (Fig. 6c). The only exception is Las Vertientes spring, with an $\mathrm{rCl} / \mathrm{rBr}$ ratio of about 7000 (not shown in the figure). The $\mathrm{rCl} / \mathrm{rBr}$ ratio of waters from the Michilla mine and the Ivan mine area deep wells have high values, about 2000 to 2400, and tend to increase with salinity.

The $\mathrm{rNa} / \mathrm{rCa}$ ratio of spring waters varies between 1 and 6.6, much less than for seawater (22). Na and $\mathrm{Ca}$ dominate over the $\mathrm{Mg}$ content, as can be seen in Figure 5 . Consequently, a variation in $\mathrm{Na}$ is approximately compensated by a similar counter-variation in Ca. Spring waters present no definite trend (Fig. 6d). In deep well waters of Ivan mine area there is a trend to increase the $\mathrm{rNa} / \mathrm{rCa}$ ratio as salinity rises, while the $\mathrm{rNa} / \mathrm{rCa}$ ratio is low in deep well waters in Michilla mine.

For spring waters, the $\mathrm{rNa} / \mathrm{rK}$ ratio tends to increase with salinity, from less than the value for seawater (50) to almost twice (Fig. 6e); values for the Ivan wells are similar. The deep well waters of Michilla mine have very high values (400 to 900), outside the common range.

Spring waters have nitrate concentrations between 9 and $60 \mathrm{mg} / \mathrm{L} \mathrm{NO}_{3}$ (Table 3). Las Vertientes spring has a value of $210 \mathrm{mg} / \mathrm{L}$. The waters of the deep wells of Ivan mine area and Michilla mine have high nitrate concentrations, between 5 and $867 \mathrm{mg} / \mathrm{L} \mathrm{NO}_{3}$.

The lithium concentration in the Ivan mine varies between 0.9 and $2.2 \mathrm{mg} / \mathrm{L}$, and the $\mathrm{rNa} / \mathrm{rLi}$ ratio varies between 1200 and 4000. It is higher than in most natural waters. For comparison, water which inflows to the southeastern sector Salar de Atacama, approximately $200 \mathrm{~km}$ to the East, has $\mathrm{rNa} / \mathrm{rLi}$ ratios between 100 and 600 , increasing with salinity.

Fig. 7 shows the ratio $\mathrm{rCa} / \mathrm{rSr}$ versus $\mathrm{rCa}$ of the springs and the deep well waters. The $\mathrm{rCa} / \mathrm{rSr}$ ratio is between 480 and 200, decreasing as salinity increases (Rissmann et al., 2015). The rCa/rSr ratio is higher in the Ca-rich waters of the Michilla mine deep wells.

For groundwater around the Spence copper deposits, in the Central Depression $100 \mathrm{~km}$ to the east of Michilla (see Fig. 1), rNa/rLi ranges between 300 and 1000 and correlates with salinity, while $\mathrm{rCa} / \mathrm{rSr}$ varies between 90 and 1000 (Leybourne and Cameron, 2006).

The waters of springs and deep wells have relatively low to quite low concentrations of silica (as dissolved $\left.\mathrm{Si}(\mathrm{OH})_{4}\right)$, between 0.5 and $21 \mathrm{mg} / \mathrm{L}$ of $\mathrm{SiO}_{2}$.

Mineral saturation indices (SI) have been calculated using the computer code PHREEQC (Parkhurst, 1995; Parkhurst and Appelo, 1999; Parkhurst et al., 2013). The spring waters are in equilibrium with respect to calcite and undersaturated with respect to gypsum, although Las Vertientes spring water is close to saturation (Table 4). Deep well waters from Michilla mine are oversaturated with respect to gypsum (Fig. 8). These results are consistent with field observations: during drilling, water yield increased when gypsum veins were intersected. In some cases, SI may present an uncertainty range of \pm 0.05 or higher, due to analytical data accuracy problems. 
Table 3.- Analytical data of chemical composition in $\mathrm{mg} / \mathrm{L}$. EC is electrical conductivity at $20^{\circ} \mathrm{C} \mathrm{in} \mathrm{mS} / \mathrm{cm}$. " $\mathrm{r}$ " means that the concentration is in meq/L. Analytical data for coastal springs are from Herrera and Custodio (2014), except for Las Conchas and Taltal springs (this investigation). For deep groundwater: 1) chemical analytical results of Ivan mine area are from the unpublished report of Montgomery and Associates (1990), and 2) chemical analytical results of Michilla mine are conducted by a member of the research team (Vargas, 2018). The ion balance error is calculated as $200(A-C) /(A+C)$, in which $A$ is the sum of anions and $C$ the sum of cations.

\begin{tabular}{|c|c|c|c|c|c|c|c|c|c|c|c|c|c|c|c|c|c|c|c|c|}
\hline Sector & Sample & $\mathrm{pH}$ & $\mathrm{T}$ & EC & $\mathrm{HCO}_{3-}$ & $\mathrm{SO}_{4}=$ & $\mathrm{Cl}-$ & $\mathrm{NO}_{3-}^{-}$ & $\mathrm{Na}+$ & $\mathrm{K}^{+}$ & $\mathrm{Ca}^{2+}$ & $\mathrm{Mg}^{2+}$ & $\mathrm{Br}$ & $\mathrm{SiO}_{2}$ & \begin{tabular}{|c} 
Ion \\
balance \\
error $\%$ \\
\end{tabular} & $\mathrm{rCl} / \mathrm{rBr}$ & $\mathrm{rNa} / \mathrm{rCl}$ & $\mathrm{rSO}_{4} / \mathrm{rCl}$ & $\mathrm{rNa} / \mathrm{rCa}$ & $\mathrm{rNa} / \mathrm{rK}$ \\
\hline \multirow{8}{*}{$\begin{array}{l}\text { Coastal } \\
\text { springs }\end{array}$} & Morro Moreno & 8.1 & 21.6 & 9 & 89 & 380 & 2500 & 20 & 1175 & 52 & 180 & 220 & 8 & 19 & $+1,0$ & 705 & 0.73 & \begin{tabular}{|l|} 
\\
0.11 \\
\end{tabular} & 5.68 & 38 \\
\hline & La Chimba & 7.3 & 17.6 & 25 & 78 & 1440 & 9200 & 18 & 4950 & 100 & 647 & 394 & 25 & 19 & $+3,1$ & 830 & 0.83 & 0.12 & 6.66 & 84 \\
\hline & Las Vertientes & 7.3 & 19 & 24 & 42 & 1640 & 6200 & 210 & 3100 & 60 & 1015 & 176 & 2 & 23 & $+5,6$ & & 0.77 & 0.20 & 2.66 & 88 \\
\hline & Cuncun & 8.2 & 23.2 & 17 & 30 & 760 & 5850 & 37 & 2758 & 60 & 707 & 352 & 16 & 22 & $-2,0$ & 825 & 0.73 & 0.10 & 3.39 & 78 \\
\hline & Panul & 8.7 & 13.5 & 2 & 81 & 122 & 360 & 60 & 133 & 7 & 126 & 38 & 1 & 16 & $-2,5$ & 812 & 0.57 & 0.25 & 0.92 & 32 \\
\hline & Perales & 7.7 & 18 & 6 & 180 & 420 & 1820 & 9 & 1018 & 26 & 185 & 129 & 6 & 15 & $-2,4$ & 684 & 0.86 & 0.17 & 4.79 & 67 \\
\hline & Taltal & 6.8 & 22.8 & 8 & 92 & 840 & 2698 & 7 & 1185 & 36 & 559 & 232 & & 2 & $-4,4$ & & 0.68 & 0.23 & & 57 \\
\hline & Las Conchas & 7.4 & 18.5 & 14 & 547 & 855 & 4454 & 0 & 2202 & 70 & 653 & 299 & & 13 & $-1,5$ & & 0.76 & 0.14 & & \\
\hline \multirow{12}{*}{$\begin{array}{l}\text { Ivan mine } \\
\text { area }\end{array}$} & WW-24 & 7 & & 72 & 24 & 1700 & 34900 & 465 & 15300 & 300 & 5100 & 875 & & 5 & $+2,7$ & & 0.68 & 0.04 & 2.61 & 87 \\
\hline & DPB-B & 7.4 & 25 & 43 & 27 & 1540 & 17226 & 137 & 7850 & 205 & 2950 & 294 & & 11 & $+0,5$ & & 0.70 & 0.07 & 2.32 & 65 \\
\hline & WW-13 & 6.9 & & 26 & 36 & 1270 & 10301 & 4 & 4200 & 93 & 2300 & 175 & 10 & 8 & $+1,1$ & 2347 & 0.63 & 0.09 & 1.59 & 77 \\
\hline & WW-3 & 7.8 & & 45 & 77 & 1350 & 14797 & 63 & 5300 & 110 & 3938 & 188 & 19 & 10 & $+0,5$ & 1804 & 0.55 & 0.07 & 1.17 & 82 \\
\hline & WW-3A & 7.1 & & 57 & 121 & 1400 & 21169 & 0 & 9100 & 207 & 4040 & 394 & 25 & 1 & $-1,1$ & 1941 & 0.66 & 0.05 & 1.96 & 75 \\
\hline & WW-8 & 7 & & 63 & 75 & 1450 & 24214 & 208 & 10800 & 244 & 4100 & 485 & 27 & 1 & $-0,4$ & 1994 & 0.69 & 0.04 & 2.29 & 75 \\
\hline & WW-10 & 6.9 & & 47 & 29 & 1400 & 22904 & 19 & 9600 & 205 & 4130 & 422 & 26 & 9 & $+1,9$ & 2003 & 0.65 & 0.05 & 2.02 & 80 \\
\hline & WW-16 & 6.5 & & 59 & 58 & 2400 & 34621 & 346 & 18000 & 185 & 3000 & 980 & 33 & 2 & $+1,5$ & 2381 & 0.80 & 0.05 & 5.22 & 165 \\
\hline & WW-19 & 7.2 & & 27 & 119 & 1160 & 10266 & 37 & 3720 & 99 & 2740 & 110 & & 13 & $+1,9$ & & 0.56 & 0.08 & 1.18 & 64 \\
\hline & WW-20 & 7.1 & & 33 & 119 & 1360 & 13629 & 132 & 6500 & 143 & 2340 & 200 & & 10 & $-0,7$ & & 0.74 & 0.07 & 2.42 & 77 \\
\hline & DPW-A & 7.2 & 25 & 31 & 30 & 1480 & 9087 & 40 & 3640 & 82 & 2360 & 110 & & 14 & $+0,3$ & & 0.62 & 0.12 & 1.34 & 75 \\
\hline & DPW-C & 7.6 & 25.5 & 24 & 23 & 1200 & 9338 & 36 & 3520 & 87 & 2480 & 96 & & 13 & $+0,8$ & & 0.58 & 0.09 & 1.23 & 69 \\
\hline \multirow{4}{*}{$\begin{array}{l}\text { Michilla } \\
\text { mine }\end{array}$} & M1 & 8.4 & 27.4 & 55 & 11 & 1186 & 23548 & 52 & 4410 & 17 & 9018 & 6 & 23.9 & 15 & $+7,0$ & 2222 & 0.29 & 0.04 & 0.43 & 441 \\
\hline & M2 & 8.7 & 28.8 & 53.4 & 10 & 2657 & 21276 & 8 & 4399 & 16 & 9540 & 2 & 21.9 & 13 & $-2,0$ & 2191 & 0.32 & 0.09 & 0.40 & 467 \\
\hline & M3 & 7.8 & 24 & 50 & 15 & 1333 & 20717 & 874 & 5619 & 11 & 6905 & 36 & 23 & 13 & $+5,5$ & 2032 & 0.42 & 0.05 & 0.71 & 868 \\
\hline & M4 & 8.0 & 26.5 & 53 & 17 & 970 & 21633 & 371 & 4812 & 14 & 8429 & 23 & & 14 & $+0,6$ & & 0.34 & 0.03 & 0.50 & 584 \\
\hline
\end{tabular}


Table 4.- Calculated logarithmic saturation indices (SI) from analytical data

\begin{tabular}{|c|c|c|c|c|c|}
\hline Sector & Sample & Calcite & Dolomite & Gypsum & $\mathrm{SiO}_{2}(\mathrm{a})$ \\
\hline \multirow{8}{*}{ Coastal springs } & Morro Moreno & $+0,45$ & $+1,31$ & $-1,19$ & $-0,76$ \\
\hline & La Chimba & $-0,15$ & $-0,24$ & $-0,43$ & $-0,69$ \\
\hline & Las Vertientes & $-0,15$ & $-0,76$ & $-0,12$ & $-0,62$ \\
\hline & Cuncun & $+0,47$ & $+0,98$ & $-0,58$ & $-0,70$ \\
\hline & Panul & $+0,93$ & $+1,53$ & $-1,41$ & $-0,79$ \\
\hline & Perales & $+0,35$ & $+0,81$ & $-1,05$ & $-0,83$ \\
\hline & Taltal & $-0,41$ & $-0,87$ & $-0,47$ & $-1,75$ \\
\hline & Las Conchas & $+0,86$ & $+1,65$ & $-0,50$ & $-0,86$ \\
\hline \multirow{12}{*}{ Ivan mine area } & WW-24 & $-0,14$ & $-0,62$ & $+0,10$ & $-1,19$ \\
\hline & DPB-B & $+0,15$ & $-0,31$ & $+0,02$ & $-0,94$ \\
\hline & WW-13 & $-0,25$ & $-1,25$ & $-0,04$ & $-1,13$ \\
\hline & WW-3 & $+1,09$ & $+1,25$ & $+0,09$ & $-1,00$ \\
\hline & WW-3A & $+0,61$ & $+0,61$ & $+0,04$ & $-2,20$ \\
\hline & WW-8 & $+0,30$ & $+0,08$ & $+0,03$ & $-2,07$ \\
\hline & WW-10 & $-0,20$ & $-0,99$ & $+0,03$ & $-0,98$ \\
\hline & WW-16 & $-0,45$ & $-0,97$ & $+0,03$ & $-1,59$ \\
\hline & WW-19 & $+0,63$ & $+0,24$ & $-0,01$ & $-0,90$ \\
\hline & WW-20 & $+0,44$ & $+0,20$ & $-0,07$ & $-1,02$ \\
\hline & DPW-A & $-0,02$ & $-0,99$ & $+0,06$ & $-0,87$ \\
\hline & DPW-C & $+0,28$ & $-0,47$ & $-0,01$ & $-0,91$ \\
\hline \multirow{4}{*}{ Michilla mine } & M1 & $+0,86$ & $-1,01$ & $+0,23$ & $-0,82$ \\
\hline & $\mathrm{M} 2$ & $+0,86$ & $-1,50$ & $+0,58$ & $-0,94$ \\
\hline & M3 & $+0,52$ & $-0,85$ & $+0,22$ & $-0,84$ \\
\hline & M4 & $+0,83$ & $-0,48$ & $+0,13$ & $-0,84$ \\
\hline
\end{tabular}

\section{${ }^{18} \mathrm{O}$ and ${ }^{2} \mathrm{H}$ results}

Figure 9 shows the plot of $\delta^{18} \mathrm{O}$ vs. $\delta^{2} \mathrm{H}$ for the coastal springs, the Ivan mine area and Michilla mine wells, two samples of rainfall obtained in Antofagasta city in the very rare, large rainfall storm in March 2015 (Jordan et al., 2015; Bozcurt et al., 2016; Wilcox et al., 2016), and the Craig (1961) world mean meteoric water line $\left(\delta^{2} \mathrm{H}=8 \delta^{18} \mathrm{O}+10 \%\right)$. Spring waters plot very close to seawater and to the rainfall water of March 2015, ranging between $+0.2 \%$ o to $-2.2 \%$ of $\delta^{18} \mathrm{O}$ and $+3.3 \%$ to $-33 \%$ o for $\delta^{2} \mathrm{H}$. Waters from deep wells in Michilla and Ivan mines are heavier, ranging between $-0.5 \%$ o to $+3 \%$ for $\delta^{18} \mathrm{O}$ and $-0.2 \%$ o to $-20 \%$ for $\delta^{2} \mathrm{H}$ (Table 5 ).

Groundwater isotopic values from different parts of northern Chile allow some general observations about the water vapor source of the precipitation that recharged the aquifers (Fig. 10). The rainwater of the highest parts of the Andes is very light compared to rainwater obtained 
in the coastal zone (Aravena et al., 1999). Thus, the groundwater obtained in the highest parts of the Andes as in Salar de Ollagüe and Ascotan and in the lagoon Tuyajto, have an isotopic composition lighter than the waters obtained in the Precordillera and Salar de Atacama (Risacher et al., 2003; Acosta et al., 2013; Rissmann et al., 2015; Herrera et al., 2016). The groundwater obtained from springs and wells of the coastal edge in general is isotopically much heavier than the waters of the highest parts of the Andes (Fig. 10).

Table 5.- Isotopic composition of $\delta^{18} \mathrm{O}$ and $\delta^{2} \mathrm{H}$ of waters from Cordillera de la Costa. Deuterium excess $=\mathrm{d}=8 \delta^{18} \mathrm{O}-\delta^{2} \mathrm{H}$

\begin{tabular}{|c|c|c|c|}
\hline Sample & $\begin{array}{c}\delta^{18} \mathrm{O}(\%) \\
\text { V-SMOW }\end{array}$ & $\begin{array}{c}\delta^{2} \mathrm{H}(\% \circ) \\
\text { V-SMOW }\end{array}$ & $\mathrm{d}(\%)$ \\
\hline Antofagasta rain & -1.2 & -3 & 6.6 \\
(March 2015) & -2.2 & -7 & 10.6 \\
\hline M1 & +1.89 & -8.4 & -23.5 \\
M2 & +1.61 & -16.5 & -29.4 \\
M4 & +1.79 & -10.2 & -24.5 \\
M5 & +1.21 & -9.2 & -18.9 \\
M6 & +1.44 & -12.5 & -24.0 \\
M7 & +1.62 & -11.7 & -24.7 \\
M8 & +1.11 & -6.70 & -15.6 \\
\hline WW-24 & +3.07 & -2 & -26.6 \\
DPW-B & +2.86 & -3 & -25.9 \\
WW-13 & +0.98 & -10.7 & -18.5 \\
WW-3 & +1.96 & -6.7 & -22.4 \\
WW-3A & +2.54 & -4.4 & -24.7 \\
WW-15 & -0.26 & -20.4 & -18.3 \\
Inside Ivan mine & +1.79 & -8.9 & -23.2 \\
\hline Morro Moreno & -0.85 & +3.3 & +10.1 \\
La Chimba & -0.09 & -3.2 & -2.5 \\
Las Vertientes & -2.22 & -33.6 & -15.8 \\
Cuncun & +0.18 & -0.4 & -1.8 \\
Panul & -1.71 & -1.8 & +11.9 \\
Los Perales & -2.2 & -10 & +7.6 \\
Las Conchas & -0.8 & -2.9 & +3.5 \\
Taltal & +0.5 & +1.9 & -2.1 \\
\hline
\end{tabular}

\section{Carbon isotopes in total dissolved inorganic carbon in spring and borehole waters}

The $\delta^{13} \mathrm{C}$ values for springs and wells are plotted versus $\mathrm{HCO}_{3}$ (Fig. 11). The data group around three $\delta^{13} \mathrm{C}$ levels, irrespective of the $\mathrm{HCO}_{3}$ concentration: -24 to $-20 \%$; -18 to $-12 \%$; -6 to $-4 \%$.

The eleven ${ }^{14} \mathrm{C}$ activity determinations of total dissolved inorganic carbon (TDIC) vary between 40 and $80 \mathrm{pmC}$ for the springs and between 17 and $28.5 \mathrm{pmC}$ for the deep wells (Table 6). Radiocarbon is subjected to isotopic exchange during the different processes from infiltration to 
the moment of sampling, as is $\delta^{13} \mathrm{C} \%$, but this fractionation is less than $2 \mathrm{pmC}$ for ${ }^{14} \mathrm{C}$. This has an insignificant influence in the interpretation of results. So, it will be neglected.

Table 6.- $\delta^{13} \mathrm{C},{ }^{14} \mathrm{C}$ and apparent ages of springs and deep wells from Cordillera de la Costa.

\begin{tabular}{|c|c|c|c|c|c|}
\hline Area & Sample & $\begin{array}{c}\mathbf{H C O}_{3} \\
(\mathbf{m g} / \mathbf{L})\end{array}$ & $\begin{array}{c}\boldsymbol{\delta}^{13} \mathbf{C}(\%) \\
\text { V-PDB }\end{array}$ & ${ }^{14} \mathbf{C}(\mathbf{p m C})$ & $\begin{array}{c}\text { Uncorrected } \\
\text { age (yr) }\end{array}$ \\
\hline $\begin{array}{c}\text { Deep wells } \\
\text { Michilla } \\
\text { area }\end{array}$ & $\mathrm{M} 1$ & 11 & -17.07 & 21.59 & 12,590 \\
& $\mathrm{M} 2$ & 10 & -22.55 & 28.47 & 10,370 \\
& $\mathrm{M} 3$ & 15 & -16.74 & 17.81 & 14,190 \\
& $\mathrm{M} 4$ & 17 & -15.77 & 17.35 & 14,400 \\
\hline \multirow{4}{*}{ Springs } & Morro Moreno & 89 & -12.5 & 55 & 4940 \\
& La Chimba & 78 & -21.1 & 65 & 3560 \\
& Las Vertientes & 42 & -21.6 & 74 & 2480 \\
& Cuncun & 30 & -14.8 & 65 & 3560 \\
& Los Perales & 180 & -13.6 & 70 & 2940 \\
& Las Conchas & 547 & -4.8 & 79.6 & 1880 \\
& Taltal & 92 & -5.8 & 39.7 & \\
\hline
\end{tabular}

\section{5.- DISCUSSION}

\section{Groundwater salinity}

Sodium chloride type waters dominate in the springs. This has been interpreted as very intense evaporation (evapo-concentration) of infiltrated precipitation, which contains wet and dry atmospheric deposition of salts, which are influenced by marine aerosols (Herrera and Custodio, 2014). Recharge incorporates soluble salts temporarily deposited in the upper soil from previous dry deposition and evaporated precipitation. Salt recycling increases as distance to the coast increases. No other chloride sources are identified in this area, as recent volcanic and hydrothermal contributions can be discarded in the area. Deposits of evaporite minerals, even in the basins where such evaporation may occur, are not known on the top and western scarp of the Cordillera de la Costa. Exceptions may occur locally, in some of the closed intra-mountain depressions or their remnants, where sediments may contain evaporite salts or unflushed old marine and highly evaporated continental waters.

The $\mathrm{rCl} / \mathrm{rBr}$ ratio for spring water is in the expected range (Custodio and Herrera, 2000; Alcalá and Custodio, 2008; Cartwrite et al. 2006) and tends to that of sea water (655) as salinity decreases (Fig. 6c). The only exception is Las Vertientes spring, with a ratio of about 7000 (not shown in the figure), pointing to the possible contribution of halite dissolution in the Salar del Carmen, in the Central Depression (Herrera and Custodio, 2014). The moderately high $\mathrm{rCl} / \mathrm{rBr}$ ratio of waters from the Ivan mine area deep wells does not point to any significant contribution of halite salt dissolution, even if the ratio tends to increase with salinity.

The expected local atmospheric chloride deposition rate is not known. Some values can be derived from other similar areas. In the arid parts of the Canary Islands (Custodio, 1992; Gasparini et al., 
1990; Herrera and Custodio, 2015) and in the semi-arid southeastern coastal Mediterranean side of the Iberian Península (Alcalá and Custodio, 2008), the long-term average atmospheric chloride deposition values vary between $10 \mathrm{~g} / \mathrm{m}^{2} / \mathrm{yr} \mathrm{Cl}$ (close to the coast) and $2 \mathrm{~g} / \mathrm{m}^{2} / \mathrm{yr} \mathrm{Cl}$ (at the nearby highlands). For the Cordillera de la Costa, deposition rate values about 3 to $6 \mathrm{~g} / \mathrm{m}^{2} / \mathrm{yr} \mathrm{Cl}$ in the coastal strip can be assumed according to average values of atmospheric chloride with distance to the coast and relief, as described in the mentioned investigations. These values possibly decrease to $<2$ to $3 \mathrm{~g} / \mathrm{m}^{2} / \mathrm{yr}$ at the higher elevations near the coast and perhaps close to the Central Depression. An influence on atmospheric $\mathrm{Cl}$ by recent post-volcanic activity within the Altiplano is neglected, as these activities occur at least $250 \mathrm{~km}$ away. Under the current hyper-arid conditions, dry deposition could probably dominate total deposition. Chloride deposition in areas with frequent camanchaca fog is not known, but the average value should be not very different to the Cordillera de la Costa highlands value.

If $C_{s}$ is the measured chloride concentration in local groundwater, neglecting the slope effect (Custodio and Jódar, 2016) for a first approach of a proxy of recharge water, the long-term average diffuse recharge rate $(R)$ is $D / C_{s}$, as chloride exportation by surface runoff can be assumed small under existing environmental conditions. $\mathrm{D}$ is total atmospheric deposition rate of $\mathrm{Cl}$. For the studied springs, most $C_{s}$ values are between 1.8 and $2.5 \mathrm{~g} / \mathrm{L} \mathrm{Cl}$, with extreme values of 0.3 and 9 $\mathrm{g} / \mathrm{L} \mathrm{Cl}$. Taking into account the position of springs to estimate $D$, the most frequent range of $R$ is 0.2 to $0.4 \mathrm{~mm} / \mathrm{yr}$, with extreme values of about 0.05 to 0.1 and 0.6 to $1.0 \mathrm{~mm} / \mathrm{yr}$. These values are the result of considering the ratio $\mathrm{D} / \mathrm{C}_{\mathrm{s}}$ and avoiding extrema values by assuming close to normal value distributions. These recharge values seem too high for current precipitation conditions, except if actual average precipitation is higher than assumed at high coastal elevations or water contribution by fog is locally significant. The other possibilities are a) recharge is mostly produced from runoff infiltration in stream channels, and b) current spring flow and salinity are remnants of a wetter-than-present past in which diffuse recharge was possible in bare rock and thin soil areas.

\section{Hydrogeochemical characteristics}

Most TDIC is derived from soil $\mathrm{CO}_{2}$, as other $\mathrm{C}$ sources, such as carbonate rocks and deep volcanic gas, are absent. For the Atacama desert, the small reported carbonate content in the upper local soils (Quade et al., 2007) is the result of carbonate precipitation. This carbonate does not dissolve in the calcium carbonate saturated soil waters (Quade et al., 2007; Quade et al., 2008). In wellvegetated areas, soil $\mathrm{CO}_{2}$ is derived from decay of vegetation and root respiration. Commonly, soil $\mathrm{CO}_{2}$ partial pressure is several times higher than that of $\mathrm{CO}_{2}$ in the open atmosphere, but in sparsely vegetated lands, biogenic $\mathrm{CO}_{2}$ production is low and when vegetation is absent the $\mathrm{CO}_{2}$ partial pressure equals that in the atmosphere or slightly exceeds it. The result is that TDIC in soil water is low, typically less than $30 \mathrm{mg} / \mathrm{L} \mathrm{HCO}_{3}$. A value down to $10 \mathrm{mg} / \mathrm{L}$ is found in Cuncun spring. This may be the result of chemical processes that decrease the initial value through calcite precipitation. TDIC values close to $100 \mathrm{mg} / \mathrm{L}$ point to significant biological activity in the soil when recharge occurred. The high $\mathrm{HCO}_{3}$ values found in Los Perales $(180 \mathrm{mg} / \mathrm{L})$ and in Las Conchas $(550$ $\mathrm{mg} / \mathrm{L}$ ) springs seem to point to well-vegetated areas and perhaps wetlands in the recharge area. Regarding deep groundwater, waters from Michilla mine also provided values down to $10 \mathrm{mg} / \mathrm{L}$ 
$\mathrm{HCO}_{3}$, as in the case of Cancun spring, suggesting the existence of chemical processes implying calcite precipitation.

The relatively low silica concentrations $\left(0.5-23 \mathrm{mg} / \mathrm{L}\right.$ of $\left.\mathrm{SiO}_{2}\right)$ indicate scarce silicate rock weathering by soil and groundwater because of low water aggressiveness due to the small $\mathrm{CO}_{2}$ partial pressure in the soil. Thus, water chemistry changes in the ground are assumed to be due to processes other than rock weathering. In comparison, the brine in the Salar de Atacama has around 80 to $90 \mathrm{mg} / \mathrm{L} \mathrm{SiO}_{2}$. In the Cordillera de la Costa there is no clear correlation with $\mathrm{HCO}_{3}$ as this last is subjected to other processes, mostly carbonate precipitation.

As shown in Figures 5 and 6 , groundwater has an $\mathrm{rNa} / \mathrm{rCl}$ ratio which is less than to much less than the marine ratio, even for the relative low salinity spring water, except in Los Perales and La Chimba springs. This cannot be explained by soil $\mathrm{CO}_{2}$ induced rock weathering.

A deep discussion of groundwater geochemistry is beyond the scope of this work, especially for the calcium-rich deep groundwater from the boreholes. The origin of Ca-rich chloride brines has been the subject of discussion for decades (Graf et al., 1966; Hanor, 1994; Drever, 1997; Houston et al, 2011; Lowenstein, 2014; Warren, 2016). In some cases, these brines are the result of seawater interaction with limestone to form diagenetic dolomite. This dolomitization has been studied in detail in coastal sebkhas (Levy, 1977), equivalent to coastal salares. But this is not the case in the northern Chile study area. Other studies explain the formation of Ca-rich chloride waters as seawater and brine evolution linked to Ca-rich volcanic rock diagenesis and zeolitization (Pastushenko, 2010; Houston, 2011), preferably in a warm environment. In this latter case the resulting groundwater is often relatively depleted in $\mathrm{Mg}, \mathrm{SO}_{4}$ and $\mathrm{HCO}_{3}$.

In the Cordillera de la Costa, calcium enrichment relative to $\mathrm{Na}$ increases from the coastal springs to groundwater in the deep wells of the two mines. Ca exceeds $\mathrm{Na}$ in deep groundwater in Michilla area. The $\mathrm{rNa} / \mathrm{rCa}$ ratio does not show a clear trend with salinity. It is quite low for Michilla wells. A plausible explanation is that pointed out above: the diagenetic interaction with rock and especially with volcanic formations, which is favored by a long transit time. The relative low $\mathrm{Mg}$ content agrees with this possibility, as well as the low $\mathrm{rSO}_{4} / \mathrm{rCl}$. The decrease of $\mathrm{K}$ concentration relative to that of $\mathrm{Na}$ can be explained by preference of $\mathrm{K}$ relative to $\mathrm{Na}$ in rock diagenesis. The increase of the $\mathrm{rCa} / \mathrm{rSr}$ ratio with increasing Ca content, up to high values, could be due to low $\mathrm{Sr}$ content in the rock. Carbonate mineral precipitation is not assumed an important additional process as TDIC concentration is low and cations much more abundant. A detailed geochemical study has not been carried out.

A working hypothesis applied to the Cordillera de la Costa groundwater differentiates between spring water and deep borehole water. Spring water is the result of recharge spanning from current to a few thousand years ago, highly concentrated by evapo-concentration and subjected to a small to moderate degree of water-rock interaction. That spring water flows at shallow depth through fractured rock, and especially volcanic rocks. In contrast, borehole water is a variable mixture of recharge water with relatively deep-seated brines, trapped by both structural features 
and its high density. The borehole waters have been subjected to diffusive dilution by shallower groundwater and have been recently hydraulically disturbed by pumping for mine drainage. It is uncertain whether old halite deposits are buried in the intra-montane depressions, although gypsum and anhydrite has been found in the mines. About $200 \mathrm{~km}$ to the north, important halite deposits exist in a similar position in the Cordillera de la Costa, and are mined.

In the transition between the Precordillera and the Central Depression at the latitude of this study (Fig. 1, Spence), along a $7 \mathrm{~km}$ long transect $\mathrm{rCl} / \mathrm{rBr}$ increases and $\mathrm{rSO}_{4} / \mathrm{rCl}$ decreases in groundwater as it flows to the west, reaching values similar to that in the deep groundwater in Ivan and Michilla (Leybourne and Cameron, 2006). However, compared to this eastern groundwater, the water in Michilla and Ivan contain more Ca relative to $\mathrm{Na}$. If there is any regional flow from the east that supplies deep groundwater in the Coastal Cordillera, it must undergo modification by water-rock reaction and ion exchange.

An important clue to the origin of the deep groundwater is its high nitrate concentration. Naturally occurring nitrate-rich evaporite salts (Pueyo et al., 1998) give rise to concentrations up to $15 \mathrm{~g} / \mathrm{L}$ of $\mathrm{NO}_{3}$ in some groundwater in the Salar de Pintados (Risacher et al., 2003), in Pampa del Tamarugal, to the north of the study area (Fig. 1). The origin of this nitrate is controversial, but it is currently assumed to be the result of atmospheric deposition in a hyper-arid environment (Seo, 2011; Pérez-Fodich, 2014) and later concentration in caliches by soil water evaporation. There is a positive correlation between $\mathrm{Na}$ and $\mathrm{NO}_{3}$ for the well waters. This is compatible with the existence of buried salares. A possible origin from the explosives used in mining operations seems unlikely as the wells are not in the mine itself. The relatively high nitrate contents in the spring waters cannot be linked to human activity in the vicinity or in the recharge areas. The atmospheric origin and concentration by intense evaporation seems a likely explanation, although supporting data are missing.

The framework within which to interpret $\delta^{13} \mathrm{C}$ in TDIC of groundwater sampled from springs and wells can be found in Quade et al. (2007). In the study area, C-3 vegetation dominates, with some crassulacean acid metabolism (CAM) vegetation adapted to fog conditions, although plants are sparse, patchy and absent in some areas. Quade et al. (2007) showed that the Coastal Cordillera C3 plants have $\delta^{13} \mathrm{C}$ of about $-23 \%$ o (VPDB), slightly higher than in other areas in order to make more efficient use of the reduced soil humidity. CAM plants have $\delta^{13} \mathrm{C}$ about $-11 \%$. Soil $\mathrm{CO}_{2}$ may reflect these values, but in areas with less than $100 \mathrm{~mm} / \mathrm{yr}$ of rainfall it is often enriched in the heavier isotope. This is due to isotopic fractionation when soil $\mathrm{CO}_{2}$ diffuses to the atmosphere, as $\mathrm{CO}_{2}$ generation rates are typically low. Under hyper-arid conditions, soil $\mathrm{CO}_{2}$ is dominantly atmospheric, whose $\delta^{13} \mathrm{C}$ is about $-7 \%$, if pre-modern conditions are considered.

The $\delta^{13} \mathrm{C}$ values for springs and wells are plotted versus $\mathrm{HCO}_{3}$ in Fig. 11. Points can be loosely grouped around three $\delta^{13} \mathrm{C}$ levels, irrespective of the $\mathrm{HCO}_{3}$ concentration. The group that clusters around $-22 \%$ may represent recharge produced in low $\mathrm{pH}$ soil environment and later evolution of DIC under closed system conditions, which may be represented by a wetland. Among this group is Las Vertientes spring, which Herrera and Custodio (2014) assumed to be discharging water from a 
shallow aquifer that crosses the Cordillera de la Costa through a canyon, possibly under wetland conditions. The intermediate group, around $-14 \%$, may represent recharge with biogenic $\mathrm{CO}_{2}$ dissolution under open conditions. Finally, the group around $-5 \%$ could represent recharge of low $\mathrm{pH}$ surface water in equilibrium with atmospheric $\mathrm{CO}_{2}$ with some dissolution of marine calcite shells and subsequent evolution under closed-to- $\mathrm{CO}_{2}$ conditions in a carbonate-free environment. The high $\mathrm{HCO}_{3}$ content precludes that recharge was produced under hyper-arid conditions with atmospheric $\mathrm{CO}_{2}$ dominating in the soil gas. Some of the hypothetical conditions noted above do not correspond to current circumstances.

The interpretation of radiocarbon data is difficult as each case may correspond to different circumstances, subjected to poorly defined conditions. There is an extensive literature about the correction of ${ }^{14} \mathrm{C}$ groundwater age to remove the contribution of non-soil generated $\mathrm{CO}_{2}$ (Pearson, 1965; Fritz and Fontes, 1986; Mook, 2002; Han et al., 2012; Plummer and Glynn, 2013). To simplify the corrections, at the expense of losing accuracy, it has been assumed that some of the samples do not incorporate other $\mathrm{C}$ sources than soil $\mathrm{CO}_{2}$ and that the other samples contain a binary mixture of carbon from two sources, 1 ) soil $\mathrm{CO}_{2}$ dissolution under open conditions (low humidity) or in a closed system (water logged soil), and 2) calcite from marine shell debris in close-to-thecoast sediments or contained in the eolian sand that rises from the coast up the coastal cliff. This is summarized in Figure 12, in which ${ }^{14} \mathrm{C}$ is plotted vs. $\delta^{13} \mathrm{C} \%$ o for coastal springs and Michilla deep wells. The Los Perales, Cuncun and Morro Moreno spring waters can be roughly considered binary mixtures of two end members: $\mathrm{HCO}_{3}$ in equilibrium with modern biogenic $\mathrm{CO}_{2}$ and old marine carbonate. The water of the Las Conchas spring may be a complex mixture of water, such as those of Los Perales, Morro Moreno and Cuncun, and water which was in equilibrium with the atmosphere (D). Marine carbonate is assumed to consist dominantly of debris of marine shells of unknown age, so a fraction may still contain ${ }^{14} \mathrm{C}$ and even be coetaneous with recharge events. The decrease of ${ }^{14} \mathrm{C}$ content by radioactive decay moves the points vertically downward in this plot. $\Delta{ }^{14} \mathrm{C}$ is the decrease in ${ }^{14} \mathrm{C}$ content. Since all water samples from Michilla plot (M-1, M-2, M-3 and $\mathrm{M}-4$ ) well to the right of the mixing lines, this points to a long residence time. After correction for radioactive decay, what is obtained is a corrected ${ }^{14} \mathrm{C}$ content to be interpreted according to the aquifer flow and recharge patterns.

\section{Sources of recharge}

The first investigation to evaluate the recharge period of the coastal waters of the north of Chile was carried out by Herrera and Custodio (2014). From the isotopic composition of water, they determined that the source of water vapor in the different springs was generated in the Pacific Ocean. However, the integration of isotopic data from groundwater with different types of observation points, including the coastal springs, the deep groundwater and the water samples from the extraordinary rainfall in Antofagasta on March 2015, allows a more integrated and complete conceptual model relative to that of Herrera and Custodio (2014).

The isotopic composition of coastal spring water generally shows values very close to that seawater, with a small deuterium excess (Table 4). This fact points to high humidity conditions at 
the time of vapor generation in the oceanic atmosphere, fast transport and intense condensation of water vapor nearby. This is what happens to modern precipitation in the coastal areas of Peru and Ecuador. The new isotopic data from the intense rainfall event in March 2015 at Antofagasta city agrees with this.

Groundwater from the deep wells in the Cordillera de la Costa has a $\delta^{18} \mathrm{O}$ and $\delta^{2} \mathrm{H}$ isotopic composition that is heavier than spring waters (Fig. 9), but shows a small deuterium excess due to a strong evaporation effect. One hypothesis is that the isotopic composition of deep well water results from mixing between strongly evaporated water, like the groundwater in the central Depression (Leybourne and Cameron, 2006) and local meteoric water with an isotopic composition that agrees with that of the coastal springs.

An alternative and more likely explanation is that deep well water represents recharge water subjected to different amounts of evaporation or mixed with highly evaporated water. In the plot of $\delta^{18} \mathrm{O}$ vs. $\delta^{2} \mathrm{H}$ (Fig. 10), if the water evaporation line or mixing line of deep well water is extrapolated to intersect the Global Mean Water Line (GMWL) with deuterium excess $d=10 \%$, the resulting point which represents original precipitation is $-10 \%$ o $\left( \pm 1 \%\right.$ o for $\delta^{18} \mathrm{O}$ and $-70 \%$ o $\left( \pm 10 \%\right.$ ) for $\delta^{2} \mathrm{H}$ (Fig. 9). This value is close to the point of intersection with the GMWL of the line corresponding to the salares in the southern Pampa del Tamarugal, about $200 \mathrm{~km}$ to the north. This water is recharged in the Andes western slope, to their east (Aravena, 1995; Acosta et al, 2013). Near $23-24^{\circ} \mathrm{S}$ latitude, the Cordillera de la Costa rainwater has $\delta^{18} \mathrm{O}$ between 0 and $-3 \%$ for $\delta^{18} \mathrm{O}$ and $\delta^{2} \mathrm{H}$ between +5 and $-10 \%$ (Fig. 10), similar to moisture from the Pacific Ocean. To the east, precipitation and groundwater $\delta^{18} \mathrm{O}$ and $\delta^{2} \mathrm{H}$ decrease. Thus, in the Andean Precordillera and the eastern edge of the Salar de Atacama ( $2300 \mathrm{~m}$ asl), values vary between -5 and $-9 \%$ for $\delta^{18} \mathrm{O}$ and -40 and $-70 \%$ for $\delta^{2} \mathrm{H}$ (Fig. 10). In the upper part of the Andean Cordillera, specifically in the Tuyajto Lake sector ( $4040 \mathrm{~m}$ asl), $\delta^{18} \mathrm{O}$ and $\delta^{2} \mathrm{H}$ vary between -9 and $-11 \%$ for $\delta^{18} \mathrm{O}$ and -70 and -90 $\%$ for $\delta^{2} \mathrm{H}$. Whether a two end-member mixing model or single source evaporation model is used, these results suggest that deep well groundwater in the Cordillera de la Costa has a contribution from precipitation which fell on the western slope of the Andes, which at this latitude is predominantly sourced from moisture coming from the Atlantic Ocean through the Amazon Basin. How this water arrived is unclear. One possibility is a shallow transfer and another is through some breaks in the Atacama fault barrier.

\section{Radiocarbon and residence time of groundwater}

The radiocarbon study of water samples obtained in different parts of the Cordillera de la Costa requires a detailed knowledge of the hydrogeological context and how the samples were obtained. Springs of the western slope of the Cordillera de la Costa would correspond to the zone of discharge where different flow lines converge and are a mixture of waters with a wide range of transit times through the unsaturated and the saturated zone. 
Within the possibilities that can be considered to estimate the average residence time of water in the aquifer, some relevant observations can be made from the $\delta^{13} \mathrm{C}$ vs. ${ }^{14} \mathrm{C}$ relation (Fig. 12). Results are summarized and commented in Table 7. The estimation of the residence time of waters of the different springs varies according to the different hypothetical flow systems. As the springs correspond to water discharges far away from each other and with very different hydrogeological contexts, the appropriate conceptual model for each spring may be different. Also, there is an important flow component parallel to the coast that converts a cross-section interpretation into a qualitative approach.

\section{Timing of aquifer recharge: Application}

La Chimba and Las Vertientes are dry stream channels. The springs in them yield water that probably infiltrated in waterlogged areas and shallow (perched?) water tables. Taking this into account, the average turnover time of these waters would be 1.0 to $2.0 \mathrm{kyr}$, which seems likely. However, the chemical composition and hydrogeological setting of water from Las Vertientes spring suggest that it may be derived from long renewal time waters moving from east to west across the Cordillera de la Costa (Herrera and Custodio, 2014). If so, the Las Vertientes ${ }^{14} \mathrm{C}$ content can be interpreted to have been increased by atmospheric exchange with the surface water entering the canyon system and infiltrating in the channel as it crosses the Cordillera de la Costa.

The water of Morro Moreno, Cuncun and Los Perales springs are located close to the mixing line between $\mathrm{HCO}_{3}$ in equilibrium with modern biogenic $\mathrm{CO}_{2}$ and old marine carbonates from shell debris (line E-B in Figure 12). In the cases of the Morro Moreno and Los Perales springs, what seems most likely is recharge produced in water-saturated land. This scenario gives an average residence time that would also be between 1.0 to $2.0 \mathrm{kyr}$.

The presence of travertine at the Taltal spring indicates that water has discharged here for possibly thousands of years. Low $\mathrm{pH}$ surface water in equilibrium with atmospheric $\mathrm{CO}_{2}$ could dissolve old carbonates before reaching the surface. For this model, the average estimated residence time is $5.0 \mathrm{kyr}$, although this is highly uncertain.

The samples obtained from the deep wells located in the galleries in Michilla mine correspond to the highest parts of the Cordillera de la Costa where there is a thick unsaturated zone, as the water table has been lowered by mining activity. The unsaturated zone is currently thicker than $500 \mathrm{~m}$ (Vargas, 2018). In this hydrodynamic context, the samples obtained at the Michilla mine correspond dominantly to locally recharged groundwater although they mix with water stored in the aquifer, with a very long time since recharge. Given their $\delta^{13} \mathrm{C}$ content and low concentration of $\mathrm{HCO}_{3}$, it is unlikely that these waters incorporate old carbonate. Hence, it is possible that their low ${ }^{14} \mathrm{C}$ results from decay during the transit through the unsaturated zone and storage time in the aquifer. Under constant recharge conditions, groundwater from the upper part of the saturated zone has a turnover time of 7 to $13 \mathrm{kyr}$, which can be assumed to approach the recharge time. If recharge was not constant, the apparent age cannot be directly related to residence time unless the relative changes in recharge rate through time are known. However, the chemical and the 
isotopic composition of these waters show that they may represent a mixture of young water with very old up conning deep saline water with no measurable ${ }^{14} \mathrm{C}$ activity.

Table 7.- Corrected radiocarbon activity of springs and deep wells estimated from Fig. $12 . \Delta^{14} \mathrm{C}$ is the vertical distance between the point and the assumed mixing line; ta is the corrected content converted into approximate age; $\tau$ is the average renewal (turnover) time in the system according to the model.

\begin{tabular}{|c|c|c|c|c|c|}
\hline Sample & Line & $\Delta^{14} \mathrm{C}$ & ta & $\tau$ & Comments regarding results \\
\hline M1 & EA & 49 & 5275 & 7527 & Waterlogging and carbonate precipitation \\
M2 & EA & 63 & 7789 & 13339 & Waterlogging and carbonate precipitation \\
M3 & EA & 50 & 5430 & 7834 & Waterlogging and carbonate precipitation \\
M4 & EA & 48 & 5123 & 7231 & Waterlogging and carbonate precipitation \\
\hline Morro Moreno & EB & 22 & 1946 & 2210 & Waterlogging \\
La Chimba & EA & 0 & 0 & 0 & Saturated land \\
Las Vertientes & EA & 21 & 1847 & 2082 & Slight waterlogging \\
& EA & 13 & 1091 & 1171 & Slight waterlogging \\
Cuncun & EB & 28 & 2573 & 3046 & Vegetated soil \\
& EA & 0 & 0 & 0 & Saturated land \\
Los Perales & EB & 13 & 1091 & 1171 & Waterlogging \\
Las Conchas & EC & 0 & 0 & 0 & Atmospheric $\mathrm{CO}_{2}$ dissolved in low pH surface water \\
& & & & & \\
Taltal & EC & 40 & 4002 & 5223 & Atmospheric $\mathrm{CO}_{2}$ dissolved in low pH surface water \\
& EB & 0 & 0 & 0 & Saturated land \\
\hline
\end{tabular}

\section{Relationship between average residence time of groundwater and paleoclimate}

As outlined above, different concepts are involved when considering groundwater flow and aquifer behavior. The ratio between water volume (storage) and total recharge, or between water column height and recharge (rate), measures the turnover time. Under steady state conditions, this turnover time is also the average residence time and the average transit time of groundwater in the aquifer system.

The residence times presented above only approach the timing of a previous wetter-than-present period if the previous climate did and the present climate does not produce significant recharge. Furthermore, the residence time would approach the historical time of enhanced recharge only if the groundwater storage below the outflow points is negligible with respect to current dynamic storage (Custodio et al, 2018).

If only coastal springs were sampled, it is not possible to know if they correspond to local 
groundwater discharge or to deep regional groundwater outflow. The new groundwater chemical and isotopic analyses, including ${ }^{14} \mathrm{C}$, from deeper than $500 \mathrm{~m}$ below the ground level in Michilla mine and the chemical and isotopic groundwater data from the Ivan mine area, permit this issue to be addressed.

The ${ }^{14} \mathrm{C}$ contents in the spring waters correspond to average residence times between 2.0 and 1.0 kyr, with one case of about $5 \mathrm{kyr}$. The radiocarbon content in the sampled waters is compatible with recharge occurring during the mid to late Holocene. Current recharge seems much less than during the inferred wet period.

The older end of this pluvial period, $5.0 \mathrm{kyr} \mathrm{BP}$, coincides with landform activity, when alluvial fans and sediment-laden stream flows were active and affecting the entire coastline of northern Chile and southern Peru (Vargas et al., 2006). The more humid climate conditions along the coast about 5.0 kyr BP were probably concentrated along the coastal strip and the Cordillera de la Costa, as this significant orographic barrier only allows very active weather systems to transport vapor further inland. Nevertheless, records from paleo-wetlands associated with springs located in the western part of the Andean Precordillera (Domeyko Range) show increased rainfall since $4.7 \mathrm{kyr}$ BP to the present (Sáez et al., 2016). There are also records from paleo-wetlands located in the eastern part of the Loa River basin and Salar de Atacama, which show rainfall between 7.0 and 3.0 kyr BP that exceeded current conditions (Rech et al., 2002). Consequently, it is reasonable that some of the humid air masses that produced precipitation in the Cordillera de la Costa could also reach some areas of the Precordillera.

Because the Michilla mine is located nearly $100 \mathrm{~km}$ north of the studied springs (Fig. 1), its hydrogeological setting differs somewhat from that of the other studied coastal springs. As mentioned above, in the case of the deep wells of the Michilla mine, it is possible to interpret that most of radiocarbon decay occurred during the transit through the unsaturated zone, or during limited lateral flow in the aquifer. If this hypothesis is acceptable, the ${ }^{14} \mathrm{C}$ activity of water would give a residence time between 7 and $13 \mathrm{kyr}$. This is compatible with recharge occurring during the late Pleistocene, when enhanced precipitation during the Central Andean Pluvial Events (CAPE) is well documented (Latorre et al. 2006). Their original $\delta^{18} \mathrm{O}$ and $\delta^{2} \mathrm{H}$ were lower than that of the coastal springs and consistent with moisture that today comes from the Atlantic Ocean (Aravena et al., 1999). A westward extension of these Andean waters was likely facilitated by the topographic gap in the Precordillera at the city of Calama (Fig. 1), through which Atlantic atmospheric water could have spilled as far west as the Cordillera de la Costa, and also groundwater recharged in the Andes could flow to the Central Depression. It is also noteworthy that the timing of the oldest recharge recognized in the Cordillera de la Costa, in Michilla, coincides with the first known inhabitants that settled on the coastal edge of the region (Marquet et al., 2012; Rebolledo et al., 2016). These apparent ages also coincide with ages obtained from fossil wood present in terraces (16.4 to $13.7 \mathrm{kyr}$ BP) in the eastern ravines in the Pampa del Tamarugal, which are indicative of perennial surface flow, currently absent in these channels (Nester et al., 2007). 
These interpretations involve a high degree of uncertainty. In addition to the assumption of uniformly distributed recharge during the wet period, these interpretations require that current recharge is nearly negligible. The uncertainty is also large because of the assumption that only a very small fraction of the aquifer water resulted from mixing with deep seated old brines, large enough to influence the chemical composition because the brines are very concentrated, but yet small enough to only modify slightly the radiocarbon content.

\section{6.- CONCLUSIONS}

Spring and well waters are of the sodium chloride type. For the coastal springs this is mainly due to concentration by evaporation in the soil of infiltrated precipitation containing dissolved salts of dry and wet atmospheric deposition, which is dominated by marine aerosols. However, deep groundwater from Michilla and Ivan mine areas is more saline than the coastal spring waters. Ca content is enhanced and becomes higher than $\mathrm{Na}$ in Michilla mine. A possible explanation is mixing with old, deep-seated brines. The chemical and the isotopic composition of $\delta^{18} \mathrm{O}$ and $\delta^{2} \mathrm{H}$ of this deep groundwater can be explained as a mixture of a small fraction of very old saline water, perhaps brine, with younger and much less saline water.

Different sources of moisture were determined from the $\delta^{18} \mathrm{O}$ and $\delta^{2} \mathrm{H}$ content of groundwater. The coastal spring water isotopic composition is heavy and similar to modern precipitation along the coastal areas of Peru and Ecuador, as well as to a recent rainstorm in Antofagasta. It is proposed that the moisture which recharged the coastal aquifers originated in the Pacific Ocean.

Waters from the deep wells in Michilla and Ivan mine areas are isotopically much heavier than spring waters and with small deuterium excess, which shows that they have undergone isotope fractionation by evaporation or are mixtures of local recharge with a highly evaporated saline water or brine. The extrapolation of the line of evaporation to intersect the Global Mean Water Line (GMWL), assuming that it represents original precipitation, points to a value typical of the groundwater draining the western slope of the Andes, whose source of humidity comes mainly from the Atlantic Ocean.

The average residence time of the waters feeding the springs varies between 1 and $2 \mathrm{kyr}$, up to 5 kyr. This average residence time coincides with a less dry span of the mid to late Holocene period indicated in many paleo-climatic studies made in the Cordillera de la Costa and in the Central Depression. This could point to a much larger recharge during the period of 5.0 to $3.0 \mathrm{kyr} \mathrm{BP}$ than at present.

The turnover time in deep wells in Michilla mine vary between 7 and $13 \mathrm{kyr}$, which overlaps with the CAPE pluvial phases described in the region for the late Pleistocene and Early Holocene. However, it cannot be ruled out that this water corresponds to a mixture of old trapped deep brines with younger, much less saline water. 
The approximate coincidence of groundwater turnover time with the timing of wet periods revealed by independent paleoclimatic data implies that recharge during these wet periods was much greater than current recharge. This could be quantified by hydrological modelling in future investigations.

\section{Acknowledgments}

This research was supported by the Anillo Project ACT1203 of the CONICYT of Chile. Part of the research time has been contributed by the Department of Civil and Environmental Engineering of the Technical University of Catalonia (UPC) and applies the results of research carried out inside Project REDESAC CICYT no CGL-2009-12910 C03. The investigation was also funded by a PhD grant CONICYT-PCHA/Doctorado Nacional/2016-21160152 of Carolina Gamboa.

\section{REFERENCES}

Acevedo, J., Herrera, H., Camacho, J., Alfaro, H. 1997. Background and geological modeling of the Susana Mine, Carolina de Michilla Area, Second Region of Antofagasta, Chile. VII Chilean Geological Congress, Vol. 2, 826-831.

Acosta, O., Guimerá, J., Custodio, E., Ansón, I., Delgado, J.L. 2013. Contribución al conocimiento de la hidrogeologia de las cuencas intraandinas del $\mathrm{N}$ de Chile [Contribution to the knowledge of northern Chile intra-Andine basin hydrogeology]. In González N., Kruse E.E., Trovatto M.M. (eds.), Agua Subterránea Recurso Estratégico. La Plata, Editorial Universidad La Plata, 118-125.

Aravena, R.; Suzuki, O.; Polastri, A., 1989. Coastal fogs and their relation to groundwater, IV Region, Chile. Chemical Geology (Isotope Geoscience Section) 79, 83-91.

Aravena, R., 1995. Isotope hydrology and geochemistry of northern Chile groundwaters Bull. Inst. Fr Études Andines 24, 495-503.

Aravena. R, Suzuki. O., Peña, H., Pollastri, A., Fuenzalida, H., Grilli, A., 1999. Isotopic composition and origin of the precipitation in Northern Chile. Appl. Geochem. 14, 411-422.

Alcalá, F., Custodio, E.. 2008. Using the $\mathrm{Cl} / \mathrm{Br}$ ratio as a tracer to identify the origin of salinity in aquifers in Spain and Portugal. Journal of Hydrology 359, 189- 207

Cereceda P, Osses P, Larrain H, Farıas M, Lagos M, Pinto R, Schemenauer R S. Advective, orographic and radiation fog in the Tarapacá region, Chile. Atmospheric Research; 2002. 64(1), 261-271.

Cartwright, I., T.R. Weaver, L.K. Fifield. $\mathrm{Cl} / \mathrm{Br}$ ratios and environmental isotopes as indicators of recharge variability and groundwater flow: An example from the southeast Murray Basin, Australia. Chemical Geology; 2006, 231, 38-56. 
Cereceda, P, Larrain, H., Osses P., Farıas, M., Egaña, I. The climate of the coast and fog zone in the Tarapacá Region, Atacama Desert, Chile. Atmospheric Research; 2008a. 87 (3-4): 301-311.

Cereceda, P, Larrain, H., Osses P., Farıas, M., Egaña, I. The spatial and temporal variability of fog and its relation to fog oases in the Atacama Desert, Chile. Atmospheric Research; 2008b. 87(3-4), 312-323.

Charrier R, Pinto L, Rodríguez M P. Tectonostratigraphic evolution of the Andean Orogen in Chile. The Geology of Chile; 2007. 21-114.

Chong G, Mendoza M, García-Veigas J, Pueyo J J, Turner P. Evolution and geochemical signatures in a Neogene forearc evaporitic basin: the Salar Grande (Central Andes of Chile). Palaeogeography, Palaeoclimatology, Palaeoecology; 1999. 151(1): 39-54.

Cortes A, González L, Binnie S A, Robinson R, Freeman S, Vargas E. Paleoseismology of the Mejillones Fault, northern Chile: Insights from cosmogenic ${ }^{10} \mathrm{Be}$ and optically stimulated luminescence determinations. Tectonics; 2012. 31(2):TC2017. Doi:10.1029/2011TC002877.

Craig, H. (1961). Isotopic variations in meteoric waters. Science, 133, 1702-1703.

Custodio, E. 1992. Coastal aquifer salinization as a consequence of aridity: the case of Amurga phonolitic massif, Gran Canaria Island. Study and Modelling of Salt Water Intrusion. 12th SWIMSalt Water Intrusion Meeting. CIMNE-UPC. Barcelona,81-98.

Custodio, E., Herrera, C.. 2000. Utilización de la relación $\mathrm{Cl} / \mathrm{Br}$ como trazador hidrogeoquímico en hidrología subterránea. Bol. Geol. Min. de España 111, 49-67.

Custodio-Ayala J, Custodio E. Hidrogeoquímica isotópica del macizo fonolítico de Amurga (SE de la Isla de Gran Canaria) [Isotopic hydrogeochemistry of the Amurga phonolitic massif (southeastern Gran Canaria Island)]. 2001. In A. Medina y J. Carrera (eds.), Las Caras del Agua Subterránea. Serie Hidrogeología y Aguas Subterráneas 1/2001. Instituto Geológico y Minero de España, Madrid ,Vol I, 461-468.

Custodio, E., Custodio-Ayala, J. 2014. Effect on radiocarbon of a rainier period content in a large water table aquifer in an arid land. 8a Asamblea Hispano-Portuguesa de Geodesia y Geofísica, Évora, Portugal 521-524

Custodio, E., Jódar, J., 2016. Simple solutions for steady-state diffuse recharge evaluation in sloping homogeneous unconfined aquifers by means of atmospheric tracers. Journal of Hydrology 540, 287-305.

Custodio, E., Jódar, J., Herrera, C., Custodio-Ayala, J., Medina, A. 2018. Changes in groundwater reserves and radiocarbon and chloride content due to a wet period in an arid climate sequence in a large unconfined aquifer. Journal of Hydrology 556, 427-437.

DGA. Levantamiento hidrogeológico para el desarrollo de nuevas fuentes de agua en áreas prioritarias de la zona norte de Chile, regiones XV, I, II y III [Hydrogeological characterization for 
the development of new water supply sources in priority areas in northern Chile, regions XV, I, II and III]. Final report VIII, Pilot system, 1st region: Salar del Huasco. S.I.T. no. 195, Dept. de Ingeniería Hidráulica y Ambiental, Pontificia Universidad Católica de Chile and Dirección General de Aguas, Santiago, Chile; 2009. http://documentos.dga.cl/REH5161v8.pdf.

Drever, J. I. The geochemistry of natural waters: Surface and groundwater environments: New Jersey, Prentice-Hall Inc.; 1997, 327-351.

Fritz, P.; Fontes, J.Ch. Handbook of environmental Isotopes; 1986. Vol 1, Elsevier.

Gasparini A, Custodio E, Fontes J C, Jiménez J, Nuñez J A. 1990. Exemple détude geochimique et isotopique aquiferes en terrain volcanique sous climat semi-aride (Amurga, Gran canaria, lles Canaries). Journal of Hidrology 114, 61-91.

Gayo, E. M., Latorre, C., Jordan, T. E., Nester, P. L., Estay, S.A., Ojeda, K. F., Santoro, C. M. 2012 a. Late Quaternary hydrological and ecological changes in the hyperarid core of the northern Atacama Desert ( 21 S). Earth-Science Reviews 113, 120-140.

Gayo, E. M., Latorre, C., Santoro, C. M., Maldonado, A., De Pol-Holz, R. 2012b. Hydroclimate variability in the low-elevation Atacama Desert over the last 2500 yr. Climate of the Past $8(1)$, $287 p$.

Garreaud, R. D. 2009. The Andes climate and weather. Advances in Geosciences; 22, 3.

Garreaud R D, Molina A, Farias M. Andean uplift, ocean cooling and Atacama hyperaridity: a climate modeling perspective. Earth and Planetary Science Letters; 2010. 292(1), 39-50.

Geyh M A, Grosjean M, Núñez L, Schotterer U. Radiocarbon reservoir effect and the timing of the late-glacial/early Holocene humid phase in the Atacama Desert (northern Chile). Quaternary Research 1999; 52(2), 143-153.

González G, Niemeyer H. Carta Antofagasta y Punta Tetas, Región Antofagasta. Servicio Nacional de Geología y Minería. Carta Geológica de Chile, Serie Geología Básica; 2005. 89(35), 1.

González L, Dunai T, Carrizo D, Allmendinger R. Young displacements on the Atacama Fault System, northern Chile from field observations and cosmogenic ${ }^{21} \mathrm{Ne}$ concentrations. Tectonics; 2006. 25(3).

Graf, D.L., Meets, W.F., Friedman, L., Shim, N.F. The origin of saline formation water, III: Calcium chloride waters. Illinois State Geological Survey, Urbana. Circular 397; 1966, 1-64.

Grosjean M, Núñez A L. Late glacial, early and middle Holocene environments, human occupation, and resource use in the Atacama (northern Chile). Geoarchaeology; 1994. 9(4), 271-286.

Grosjean M, Núñez L, Cartajena I, Messerli B. Mid-Holocene climate and culture change in the Atacama Desert, northern Chile. Quaternary Research; 1997. 48(2): 239-246. 
Grosjean, M., Valero-Garcés, B.L., Geyh, M.A., Messerli, B, Schotterer, U, Schreier, H., and Kelts, K., 1997, Mid-and late-Holocene limnogeology of Laguna del Negro Francisco, northern Chile, and its palaeoclimatic implications: The Holocene, v. 7, p. 151-159.

Grosjean M, Van Leeuwen J F N, Van Der Knaap W O, Geyh M A, Ammann B, Tanner W, Veit H. A $22,000{ }^{14} \mathrm{C}$ year BP sediment and pollen record of climate change from Laguna Miscanti (23 S), northern Chile. Global and Planetary Change; 2001. 28(1): 35-51.

Grosjean M, Cartajena I, Geyh M A, Núñez L. From proxy data to paleoclimate interpretation: the mid-Holocene paradox of the Atacama Desert, northern Chile.Palaeogeography, Palaeoclimatology, Palaeoecology; 2003. 194(1), 247-258.

Han, L-F., Plummer, L.N., Aggarwal, P. (2012). A graphical method to evaluate predominant geochemical processes occurring in groundwater systems for radiocarbon dating. Chemical Geology, 318-319: 88-112.

Hanor, J. S., 1994, Origin of saline fluids in sedimentary basins. Geological Society, London, Special Publications; 1994, 78, 151-174.

Hartley, A. J., Chong, G. (2002). Late Pliocene age for the Atacama Desert: Implications for the desertification of western South America. Geology, 30(1), 43-46.

Herrera C, Custodio E. Origin of waters from small springs located at the northern coast of Chile, in the vicinity of Antofagasta. Andean Geology; 2014. 41(2): 314-341.

Herrera C, Custodio E. Groundwater flow in a relatively old oceanic volcanic island: The Betancuria area, Fuerteventura Island, Canary Islands, Spain. Science of the Total Environment; 2015. 496: 531-550.

Houston J, Hart D. Theoretical head decay in closed basin aquifers: an insight into fossil groundwater and recharge events in the Andes of northern Chile. Quarterly Journal of Engineering Geology and Hydrogeology 2004; 37(2), 131-139.

Houston J. Variability of precipitation in the Atacama Desert: its causes and hydrological impact. International Journal of Climatology 2006; 26(15): 2181-2198.

Houston J. Recharge to groundwater in the Turi Basin, northern Chile: an evaluation based on tritium and chloride mass balance techniques. Journal of Hydrology; 2007. 334(3), 534-544.

Houston, S., Smalley,C., Laycock, A., Yardley, B. W. D., The relative importance of buffering and brine inputs in controlling the abundance of $\mathrm{Na}$ and $\mathrm{Ca}$ in sedimentary formation waters: Marine and Petroleum Geology; 2011, 28, 1242-1251.

IAEA/WMO. Global Network of Isotopes in Precipitation. The GNIP Database; 2015. Accessible at: http://www.iaea.org/water.

Jódar J, Lambán L J, Medina A, Custodio, E. Exact analytical solution of the convo- lution integral 
for classical hydrogeological lumped-parameter models and typical input tracer functions in natural gradient systems. Journal of Hydrology; 2014. 519, 3275-3289.

Jordan T, Riquelme R, González G, Herrera C, Godfrey L, Colucci S, Gironás León J, Gamboa C, Urrutia J, Tapia L, Centella K, Ramos H. Hydrological and geomorphological consequences of the extreme precipitation event of 24-26 March 2015, Chile. XIV Geological Congress of Chile, 2015, 777-780.

Jordan, T.E., Herrera L., C., Godfrey, L.V., Colucci, S.J., Gamboa P., C., Urrutia M., J., González L., G., and Paul, J., 2018, Isotopic Characteristics and Paleoclimate Implications of the Extreme Rain Event of March 2015 in Northern Chile: Andean Geology,

Jordan T E, Kirk-Lawlor, N E, Blanco N P, Rech J A, Cosentino N J. Landscape modification in response to repeated onset of hyperarid paleoclimate states since $14 \mathrm{Ma}$, Atacama Desert, Chile. Geological Society of America Bulletin; 2014. 126(7-8), 1016-1046.

Kay S M, Ramos V A, Mpodozis C, Sruoga P. Late Paleozoic to Jurassic silicic magmatism at the Gondwana margin: Analogy to the Middle Proterozoic in North America?. Geology; 1989. 17(4), 324-328.

Latorre C., Betancourt J.L., Rylander K.A., Quade J. (2002). Vegetation invasions into absolute Desert: A 45,000-yr rodent midden record from the Calama-Salar de Atacama basins, northern Chile (22-24 S). Geol Soc Am Bull 114:349-366.

Latorre, C., Betancourt, J. L., Arroyo, M. T. (2006). Late Quaternary vegetation and climate history of a perennial river canyon in the Río Salado basin (22 S) of Northern Chile. Quaternary Research, 65(3), 450-466.

Latorre C, Santoro C M, Ugalde P C, Gayo E M, Osorio D, Salas-Egaña C, De Pol-Holz R, Joly D, Rech J A. Late Pleistocene human occupation of the hyperarid core in the Atacama Desert, northern Chile. Quaternary Science Reviews; 2013. 77: 19-30.

Levy, Y. The origin and evolution of brine in coastal sebhas, northern Sinai. Journal of Sedimentary Research; 1977, 47(1), 451-462.

Leybourne, M A, Cameron, E M Composition of groundwaters associated with porphyry-Cu deposits, Atacama Desert, Chile: Elemental and isotopic constraints on water sources and waterrock reactions. Geochimica et Cosmochimica Acta: 2006 70: 1616-1635.

Lowenstein, T., Kendall, B., Anbar, A. D. The geologic history of seawater, Chapter 8.21. Treatise on Geochemistry (2nd Edition), Elsevier; 2014, 569-621.

Lucassen F, Franz G. (1994). Arc related Jurassic igneous and meta-igneous rocks in the Coastal Cordillera of northern Chile/Region Antofagasta. Lithos, 32 (3-4), 273-298. 
Marquet P A, Santoro C M, Latorre C, Standen V G, Abades S R, Rivadeneira M M, Arriaza B, Hochberg $M$ E. Emergence of social complexity among coastal hunter-gatherers in the Atacama Desert of northern Chile 2012; 109 (37): 14754-14760.

Martí Antón N. Caracterización hidrogeoquímica e isotópica de la cuenca del Loa Alto, región de Antofagasta, Chile [Hydrogeochemical and isotopic charactesization of Loa Alto basin, Antofagasta Regio, Chile]. Ms Thesis in Geotechnical and Sismic Engeneering. Dep. of GeoEngineering, Technical University of Catalonia, Barcelona; 2014. 1-254.

Montgomery Associates, Inc. Results of Quebrada El Desesperado groundwater exploration program and results of well construction for pilot production wells DPW-A, DPW-B, and DPW-C. Mina Ivan project, Antofagasta, Chile. Prepared for Minera Rayrock, Ltda. Unpublished report 1990; $115 \mathrm{p}$.

Mook, W.G. Isótopos ambientales en el ciclo hidrológico: principios y aplicaciones [Environmental isotopes in the hydrological cycle: principles and applications]. Instituto Geológico y Minero de España; 2002. Madrid: 1-596.

Nester P L, Gayo E, Latorre C, Jordan T E, Blanco N. Perennial stream discharge in the hyperarid Atacama Desert of northern Chile during the latest Pleistocene. Proceedings of the National Academy of Sciences; 2007. 104(50), 19724-19729.

Núñez L, Varela J. Sobre los recursos de agua y el poblamiento prehispánico de la Costa del Norte Grande de Chile. Estudios Arqueológicos, Departamento de Arqueología y Museos, Universidad de Chile; 1968. Vol. 3-4: 1-41. Antofagasta.

Parkhurst, D.L. User's guide to PHREEQC-A computer program for speciation, reaction-path, advective-transport, and inverse geochemical calculations. United States Geological Survey WaterResources Investigations Report; 1995. 95-4227: 1-143.

Parkhurst D L, Appelo C A J. User's guide to PHREEQC (version 2) - a computer program for speciation, reaction-path, 1D-transport, and inverse geochemical calculations. US Geol. Surv. Water Resour. Inv. Rep; 1999. 99-4259, 312p.

Parkhurst, D.L., Appelo, C.A.J., 2013. Description of input and examples for PHREEQC Version 3. A Computer Program for Speciation, Batch Reaction, One Dimensional Transport, and Inverse Geochemical Calculations. In: U.S. Geological Survey (Ed.), Techniques and Methods, Book 6, Chap. A43. U.S. Geological Survey, Denver, Colorado.

Pastushenko, Y.N. Origin of calcium-chloride brines in Middle Jurassic volcanic deposits (Western Caucasus). International Geology Reviews; (2010). 9(5), 691-698.

Pearson, F. J. Use of C-13/C-12 ratios to correct radiocarbon ages of material initially diluted by limestone, paper presented at Sixth International Conference on Radiocarbon, U.S. At. Energy Comm., Pullman, Wash.; 1965. 
Placzek C, Quade J, Betancourt J L, Patchett P J, Rech J A, Latorre C, English N B. Climate in the dry central Andes over Geologic, Millennial, and Interannual Timescales1. Annals of the Missouri Botanical Garden; 2009. 96(3), 386-397.

Plummer, L.N., Glynn, P.D. Radiocarbon dating in groundwater systems. In Isotope Methods for Dating Old Groundwater. IAEA, Intern. Atomic Energy Agency; 2013. Vienna: 33-89.

Pueyo, J.J.; Chong, G.; Vega, M. Mineralogía y evolución de las salmueras madres en el yacimiento de nitratos Pedro de Valdivia, Antofagasta, Chile. Revista Geológica de Chile; 1998. 25 (1): 3-15.

Quade J, Rech J A, Latorre C, Betancourt J L, Gleeson E, Kalin M T K. Soils at the hyperarid margin: The isotopic composition of soil carbonate from the Atacama Desert, Northern Chile. Geochimica et Cosmochimica Acta; 2007. 71(15): 3772-3795.

Quade J, Rech J A, Betancourt J L, Latorre C, Quade B, Rylander K A, Fisher T. Paleowetlands and regional climate change in the central Atacama Desert, northern Chile. Quaternary Research; 2008. 69(3), 343-360.

Pérez-Fodich, A., Reich, M., Álvarez, F., Snyder, G.T., Schoenberg, R., Vargas, G., Maramatsu, Y., Fehn, U. Climate change and tectonic uplift triggered the formation of the Atacama Desert's giant nitrate deposits. Geology, The Geological Society of America; 2014, 42, 251-254.

Rebolledo S, Béarez P, D Salazar, Fuentes F. Maritime fishing during the Middle Holocene in the hyperarid coast of the Atacama Desert. Quaternary International; 2016. 391, 3-11.

Rech J A, Quade J, Betancourt J L. Late Quaternary paleohydrology of the central Atacama Desert (lat 22-24 S), Chile. Geological Society of America Bulletin; 2002. 114(3), 334-348.

Rech, J. A., Quade, J., Hart, W. S. 2003. Isotopic evidence for the source of Ca and S in soil gypsum, anhydrite and calcite in the Atacama Desert, Chile. Geochimica et Cosmochimica Acta; 2003., 67(4), 575-586.

Rech J. A, Currie B S, Michalski G, Cowan A M. Neogene climate change and uplift in the Atacama Desert, Chile. Geology; 2006. 34(9), 761-764.

Rissmann C, Leybourne M, Benn C, Christenson B. The origin of solutes within the groundwaters of a high Andean aquifer. Chemical Geology; 2015. 396: 164-181.

Risacher F, Alonso H, Salazar C. The origin of brines and salts in Chilean salars: a hydrochemical review. Earth-Science Reviews; 2003. 63, 249-293.

Roman, R. 1999. Obtención del agua potable por métodos no tradicionales. Ciencia al Día Internacional. Tecnología y Ciencias de la Tierra. Chile.

Sáez, A., Cabrera, L., Jensen, A., and Chong, G., 1999. Late Neogene lacustrine record and palaeogeography in the Quillagua-Llamara basin, Central Andean fore-arc (northern Chile). Palaeogeography, Palaeoclimatology, Palaeoecology 151, 5-37. 
Sáez, A., Godfrey, L.V., Herrera, C., Chong, G., Pueyo, J.J., 2106. Timing of wet episodes in Atacama Desert over the last $15 \mathrm{Ky}$. The Groundwater Discharge Deposits (GWD) from Domeyko Range at $25^{\circ}$ S. Quaternary Science Reviews 145, 82-93.

Salas I, Herrera C, Luque, J A, Delgado J, Urrutia J, Jordan T. Recent climatic events controlling the hydrological and the aquifer dynamics at arid areas: The case of Huasco River watershed, northern Chile. Science of the Total Environment; 2016. 571, 178-194.

Scheuber E, Gonzalez G. Tectonics of the Jurassic-Early Cretaceous magmatic arc of the north Chilean Coastal Cordillera $\left(22^{\circ}-26^{\circ} \mathrm{S}\right)$ : A story of crustal deformation along a convergent plate boundary. Tectonics; 1999. 18(5), 895-910.

Seo, J. Solving the mystery of the Atacama nitrate deposits: The use of stable oxygen isotope analysis and geochemistry. Journal of Purdue Undergraduate Research; 2011, 1, 38-45. doi: 10.5703/jpur.01.1.6

Squeo, F.; Aravena, R.; Aguirre, E.; Pollastri, A.; Jorquera, C.; Ehleringer, J. 2006. Groundwater dynamics in a costal aquifer in north-central Chile: Implications for groundwater recharge in an arid ecosystem. Journal of Arid Environments, 67: 240-254.

Vargas G, Ortlieb L, Rutllant J. Aluviones históricos en Antofagasta y su relación con eventos El Niño/Oscilación del Sur. Revista Geológica de Chile; 2000. 27(2), 157-176.

Vargas G, Rutllant J, Ortlieb L. ENSO tropical-extratropical climate teleconnections and mechanisms for Holocene debris flows along the hyperarid coast of western South America (17-24 S). Earth and Planetary Science Letters; 2006. 249(3), 467-483.

Vargas J. Caracterización hidrogeológica e hidrogeoquímica de las aguas subterráneas de la mina Estefanía, Minera Michilla, II Región de Chile; 2018. 130p

Warren, J. K., 2016, Evaporites: A Compendium: Berlin, Springer, 1-1854. ISBN 978-3-319-13511-3.

Zuber A. Mathematical models for the interpretation of environmental radioisotopes in groundwater systems. In: Fritz, P. and Fontes, J-C (eds.): Handbook of Environmental Isotope Geochemistry; 1986. V.2., Elsevier, Amsterdam: 1-59. 


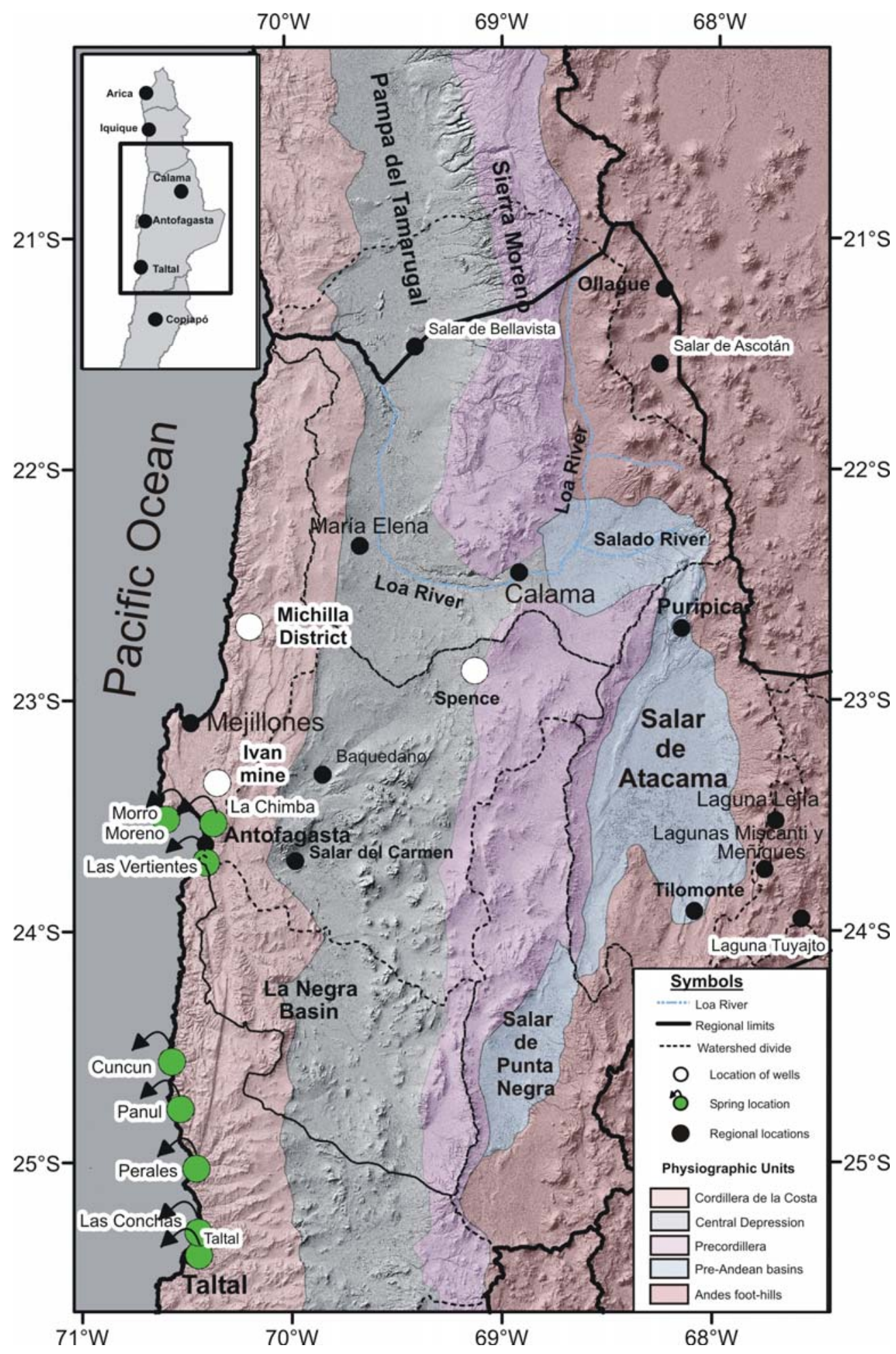

Fig. 1.- Digital elevation model (DEM) of the considered area that shows the location of the springs and deep wells of the study area. The names of the more important locations of the Second Region (Antofagasta) of Chile are given. 


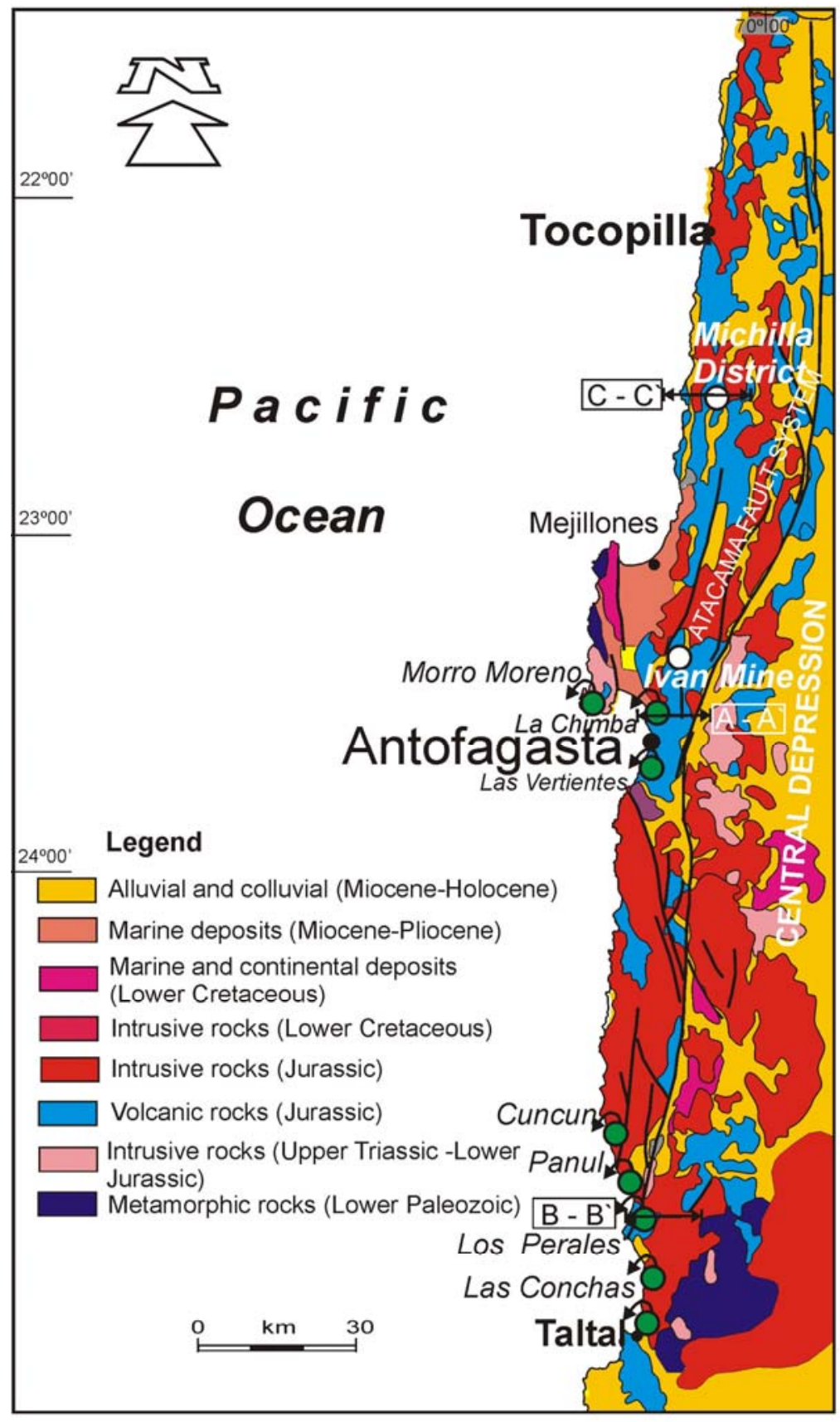

Fig. 2.- Geologic map of the Cordillera de la Costa in the Antofagasta Region and location of the simplified hydrogeological cross-sections in Fig. 3 and Fig. 4. 

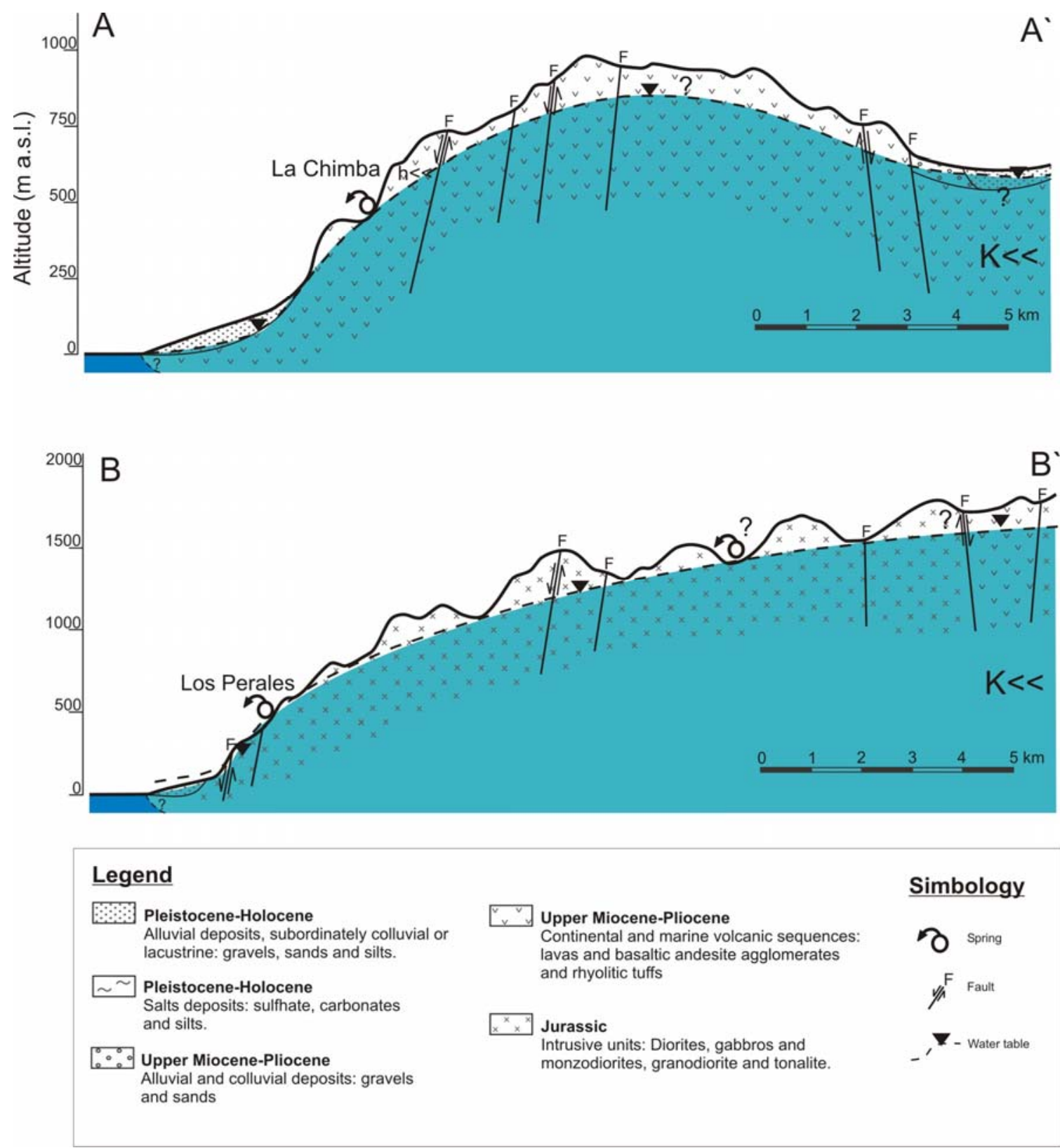

Fig. 3.- Idealized hydrogeological cross section of the coastal aquifers in Antofagasta area. Rocks are of very low permeability and of low permeability in the upper part (with points) and are much more heterogeneous than shown. 
C

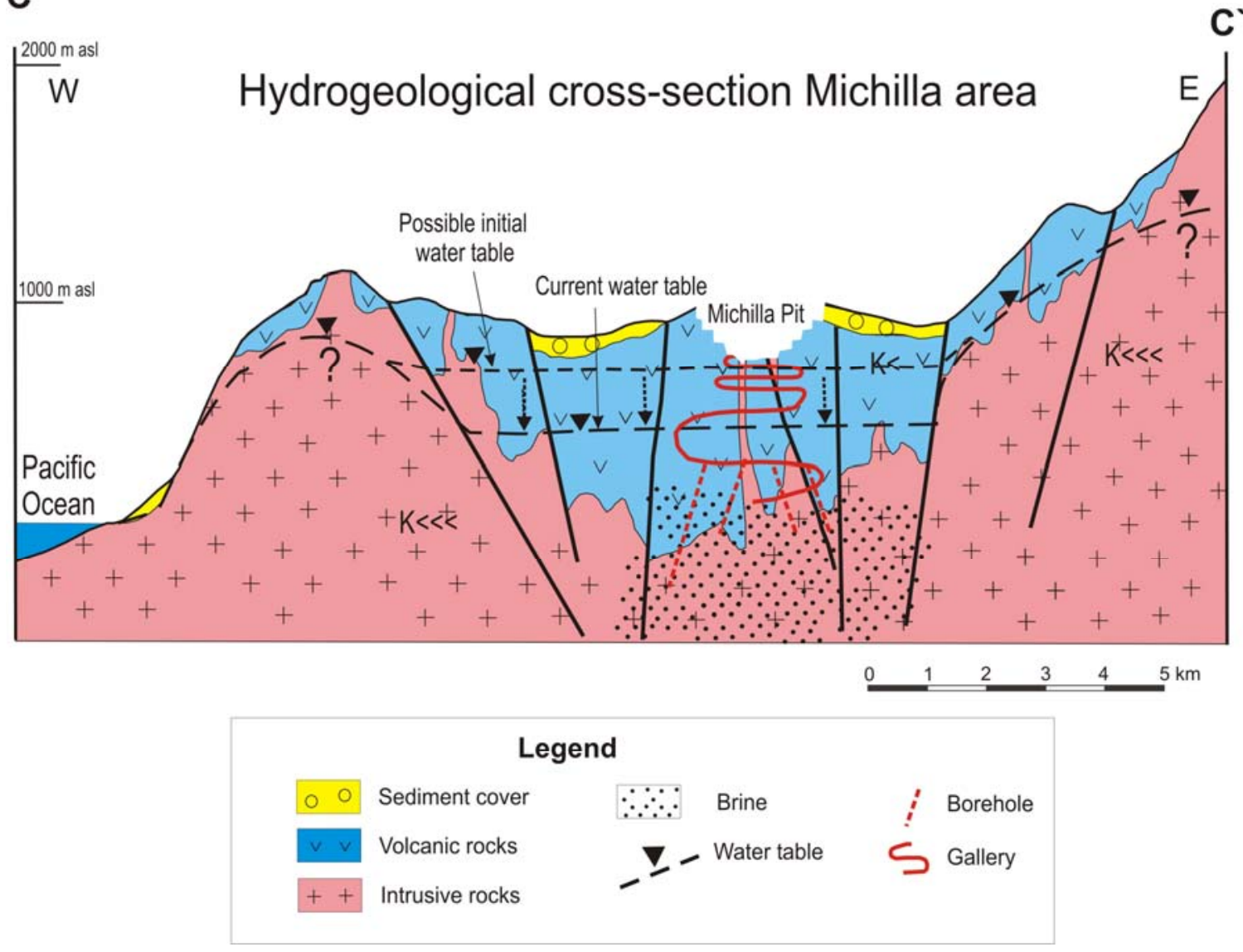

Fig. 4.- W-E idealized hydrogeological cross-section of the Michilla area. Geology modified and extended from Acevedo et al. (1997). $K \ll<<$ means very low permeability. 


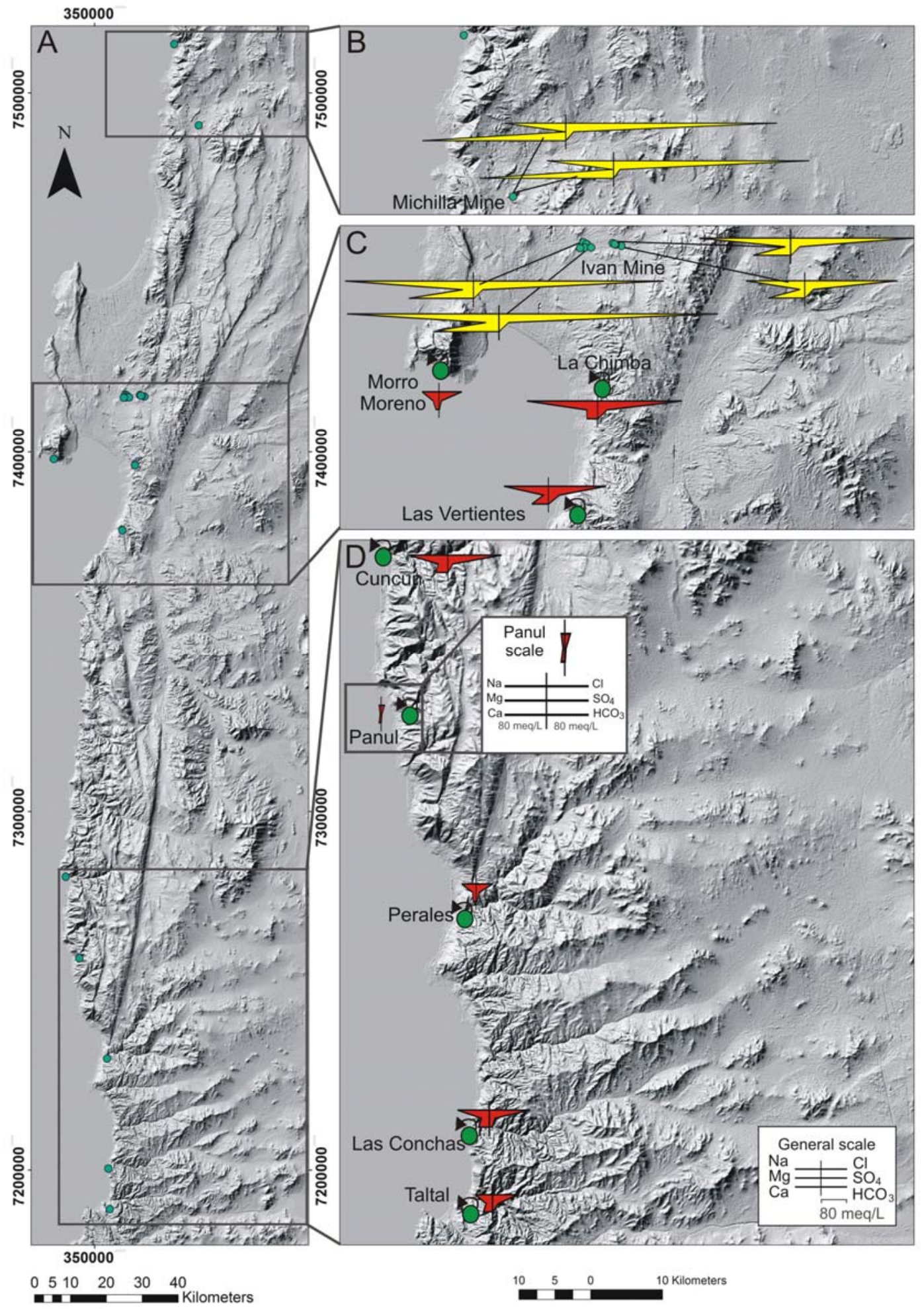

Fig. 5. Modified Stiff diagrams of the waters from Michilla mine and Ivan mine deep wells, and the coastal springs. 


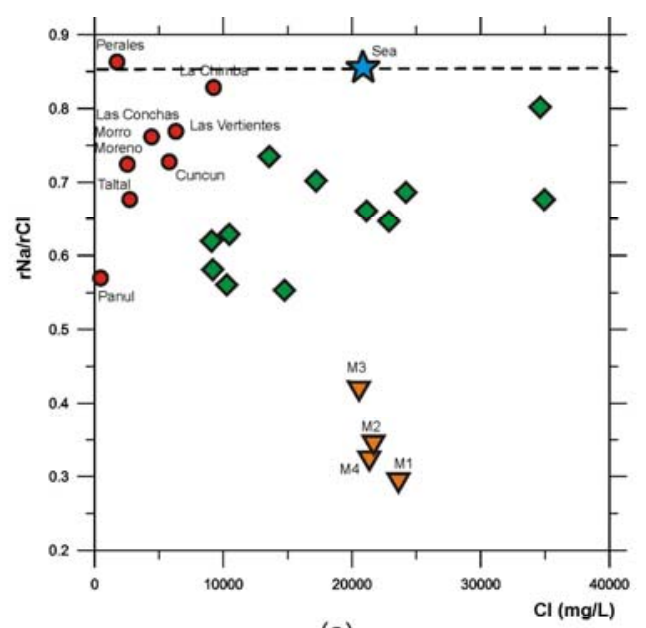

(a)

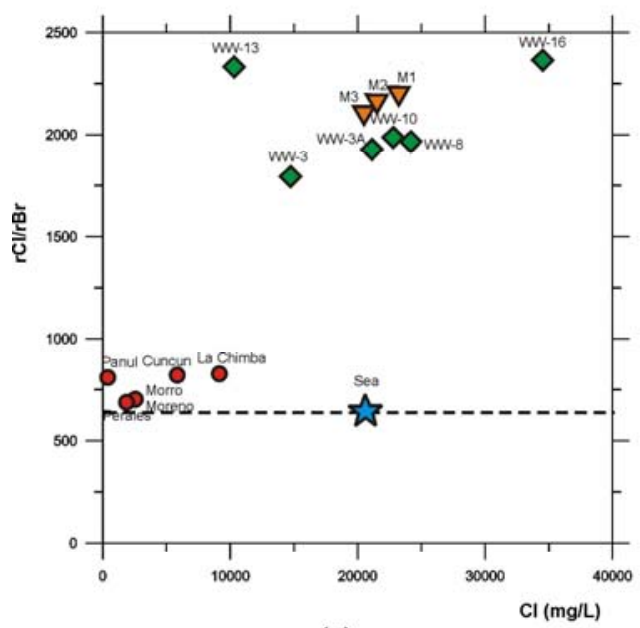

(c)

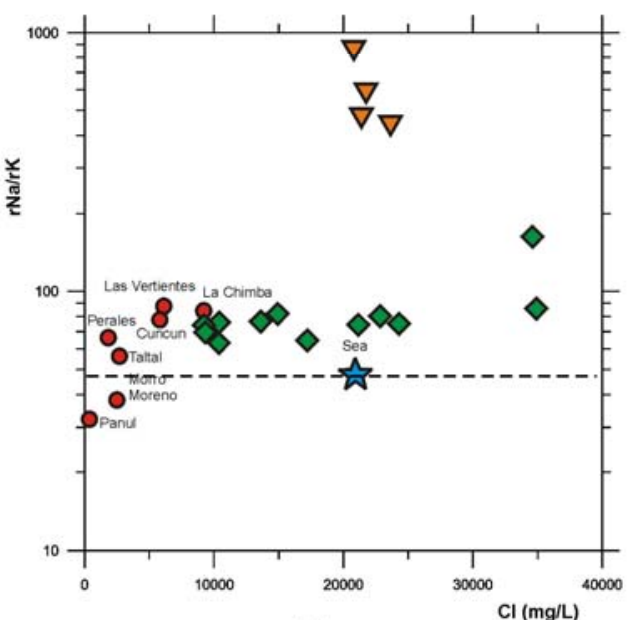

(e)

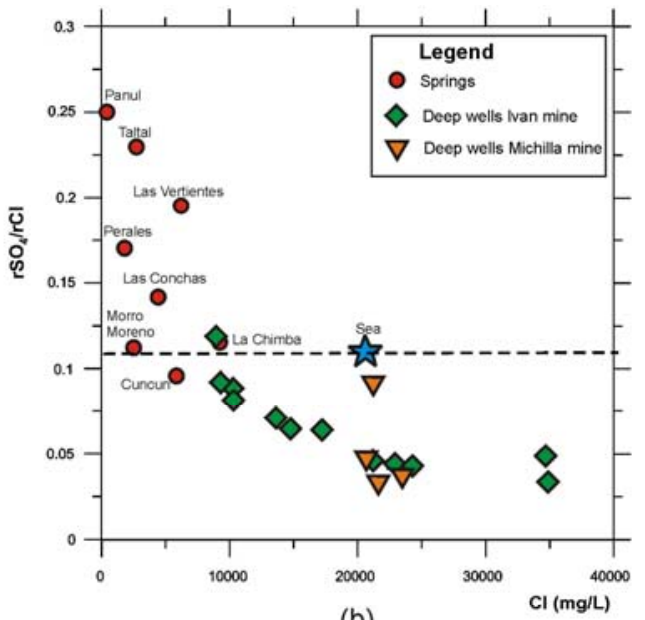

(b)

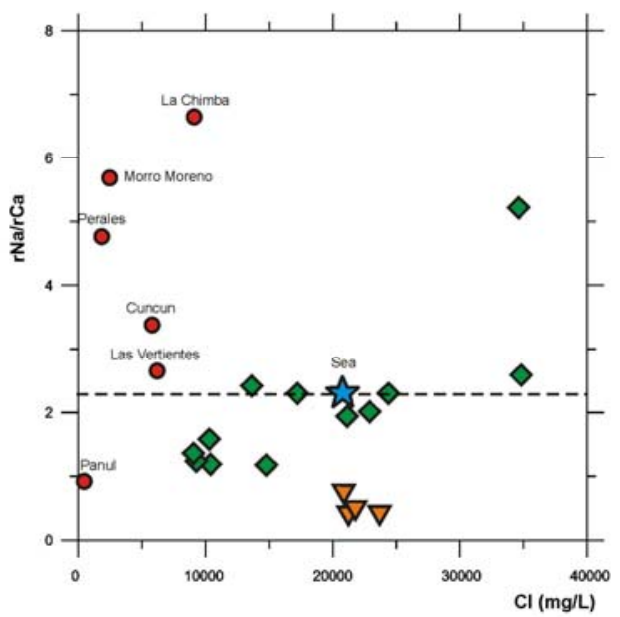

(d)

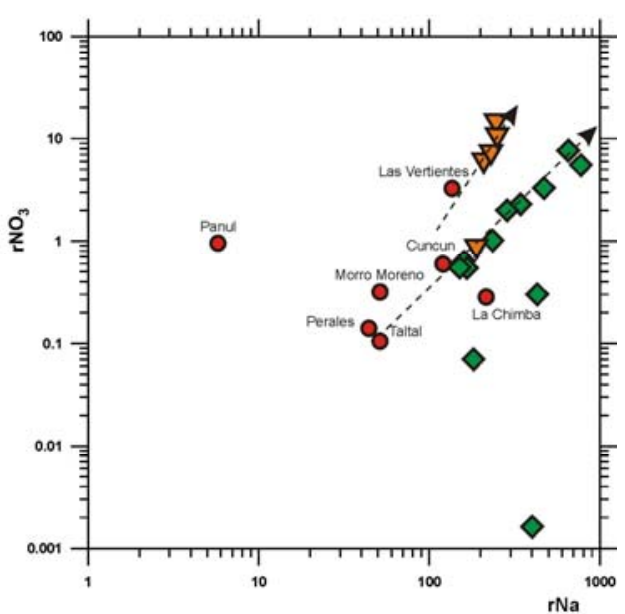

(f)

Fig. 6.- Hydrochemical bivariate plots of ions and ionic ratios. a) $\mathrm{rNa} / \mathrm{rCl}$, b) $\mathrm{rSO} / \mathrm{rCl}, \mathrm{c}$ ) $\mathrm{rCl} / \mathrm{rBr}$ (Las Vertientes springs are not plotted as the ratio is about 7000), d) $\mathrm{rNa} / \mathrm{rCa}$ (the marine ratio is not plotted as it is about 22), e) $\mathrm{rNa} / \mathrm{rK}$ ratios of springs and deep wells in Cordillera de la Costa waters vs. $\mathrm{Cl}$, and f) $\mathrm{rNO}_{3}$ vs. rNa. The prefix ' $r$ ' means that concentrations are in $\mathrm{meq} / \mathrm{L}$. Seawater is shown by a large blue star. Dotted line denotes the specific ionic ratio of sea water (for plot ' $a$ ' to ' $e$ ') and the geochemical trends of groundwater (for plot ' $f$ '). 


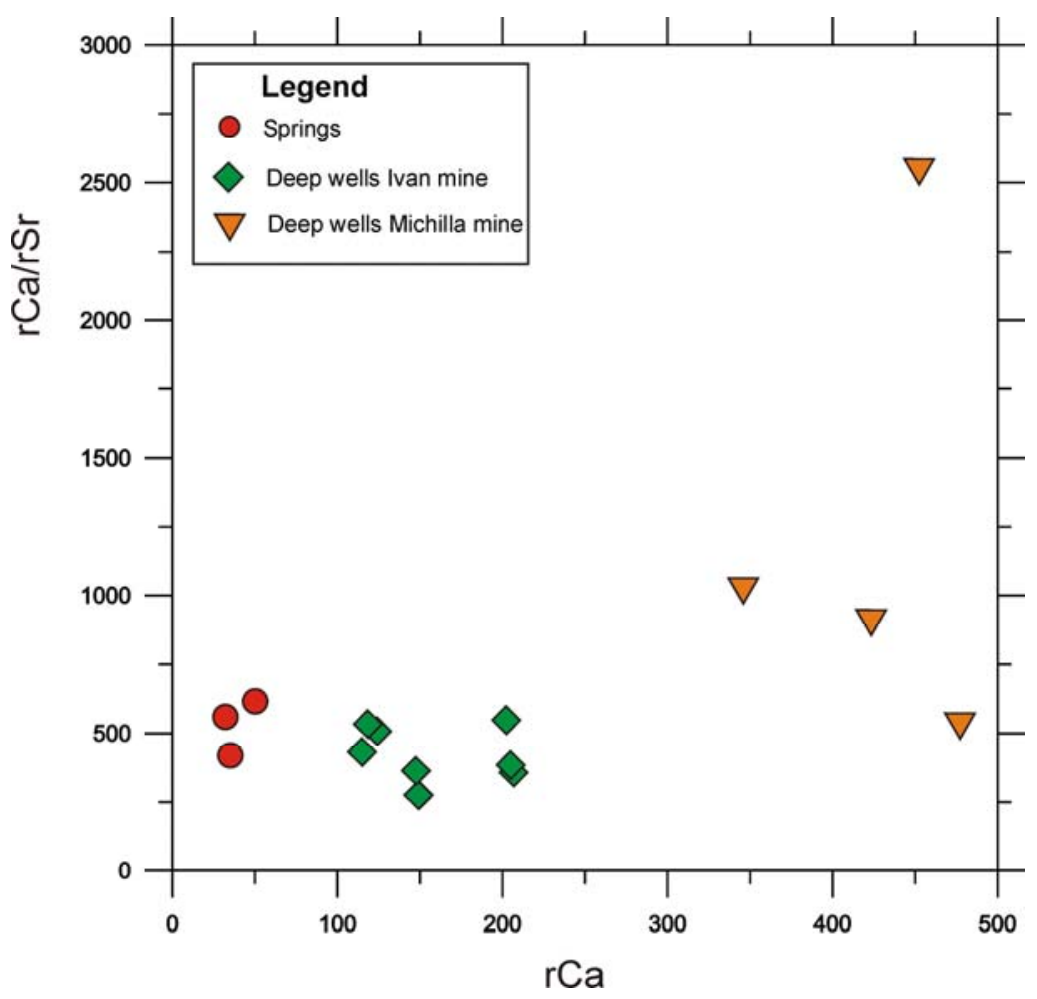

Fig. 7.- Comparison between $\mathrm{rCa} / \mathrm{rSr}$ ratio versus $\mathrm{rCa}$ of springs and deep wells in Cordillera de la Costa waters.

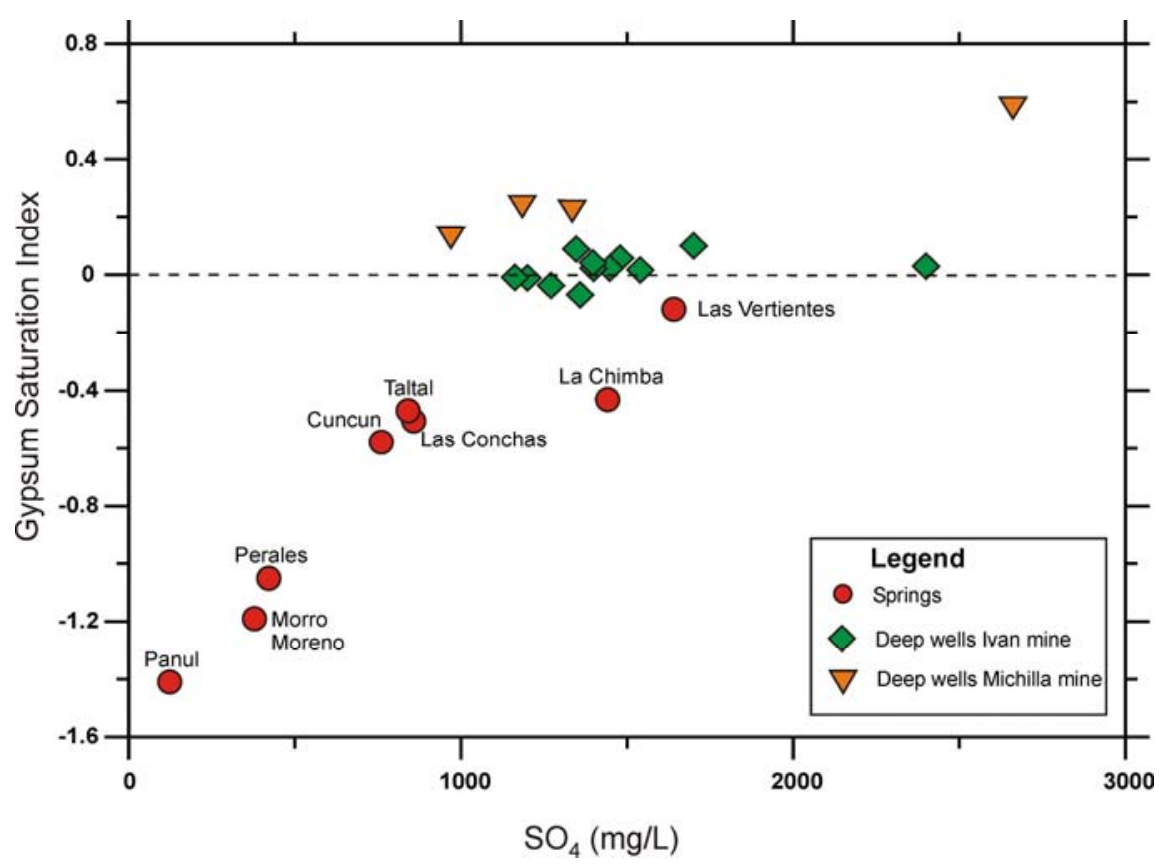

Fig. 8.- Comparison gypsum saturation index as a function of dissolved sulfate content for springs and deep wells in the Cordillera de la Costa. 


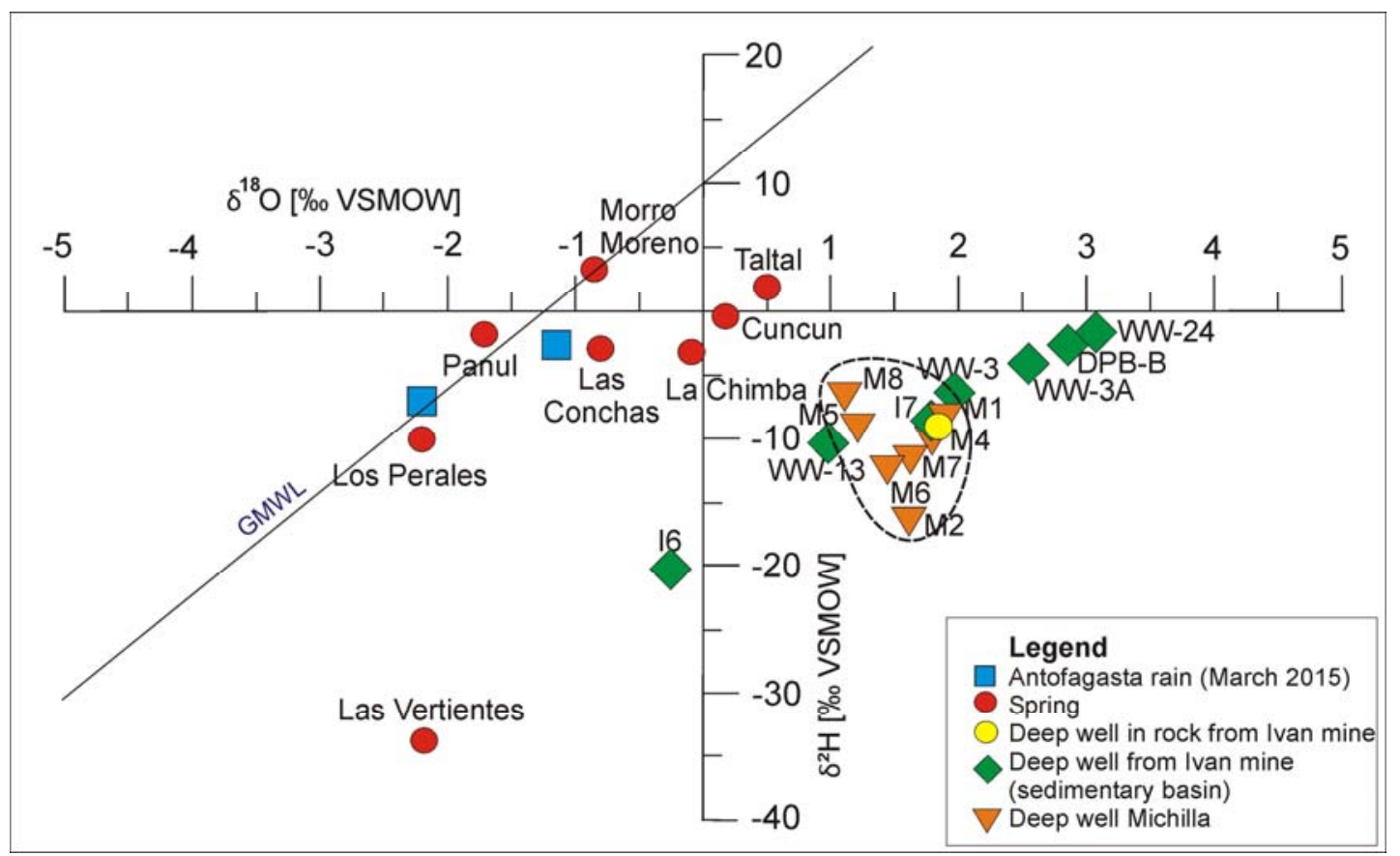

Fig. 9.- Plot of $\delta^{18} \mathrm{O}$ vs. $\delta^{2} \mathrm{H}$ data from coastal springs (from Herrerand Custodio, 2014) and the Ivan and Michilla deep wells (from this study) in the Cordillera de la Costa. GMWL= Global Mean Water Line. 


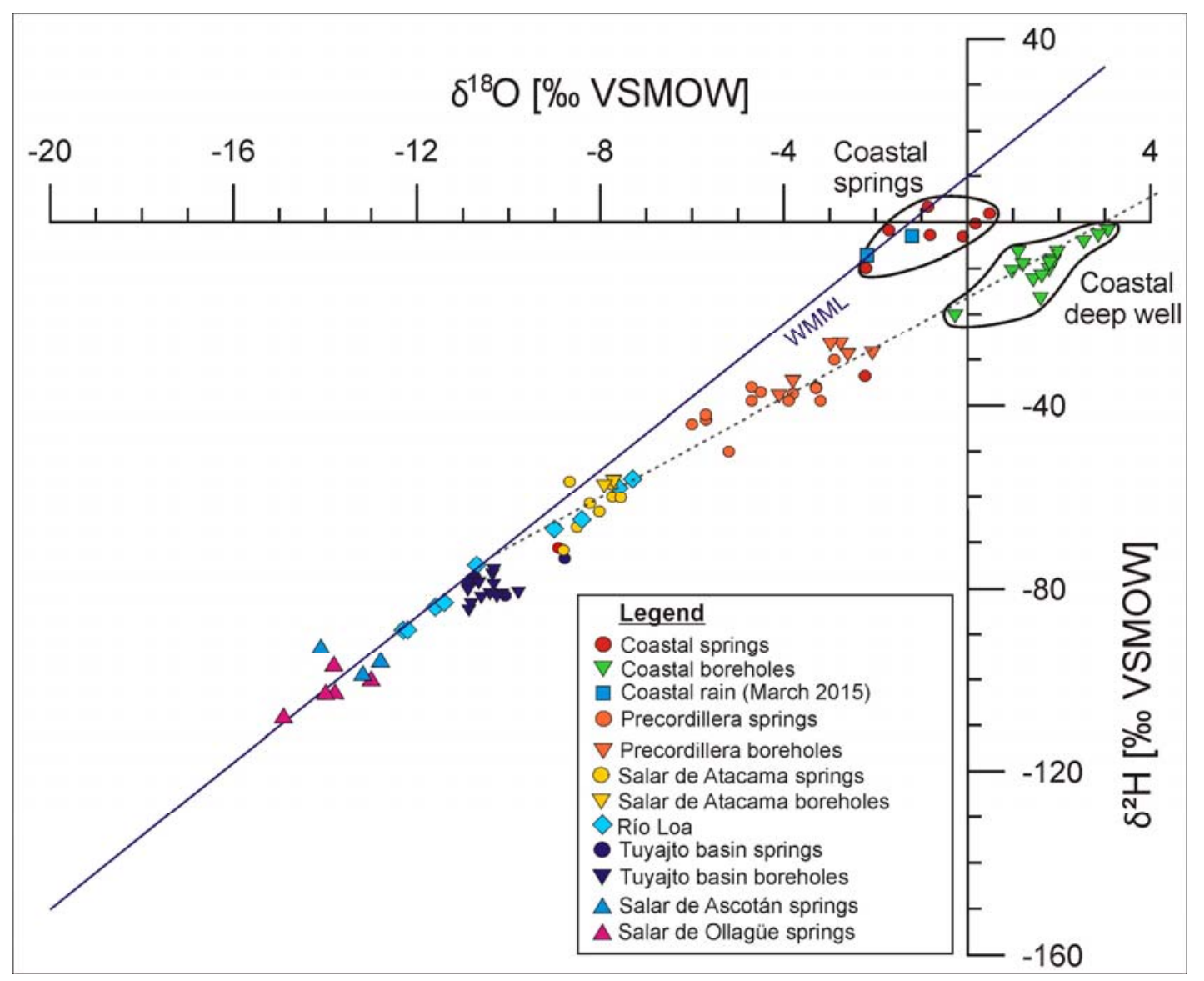

Fig. 10.- Plot of $\delta^{18} \mathrm{O}$ vs. $\delta^{2} \mathrm{H}$ data of: a) coastal springs (data from Herrera and Custodio, 2014) and the Ivan and Michilla deep wells (data from this study), b) other groundwater of inner regions in northern Chile (data from this study), c) two (2) rain samples of Antofagasta (data from this study), and d) Global Mean Water Line (GMWL). 


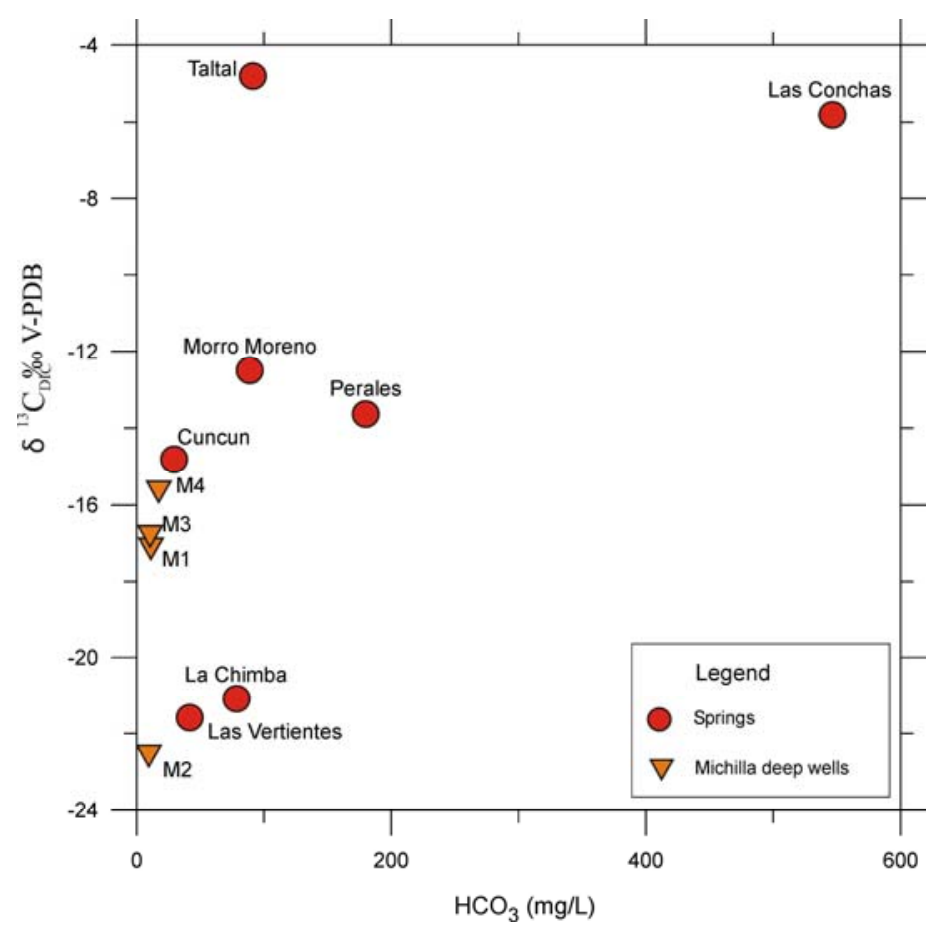

Fig. 11.- Plot of $\delta^{13} \mathrm{C}$ vs. $\mathrm{HCO}_{3}$ (mg/L) for coastal springs and Michilla area deep wells. 


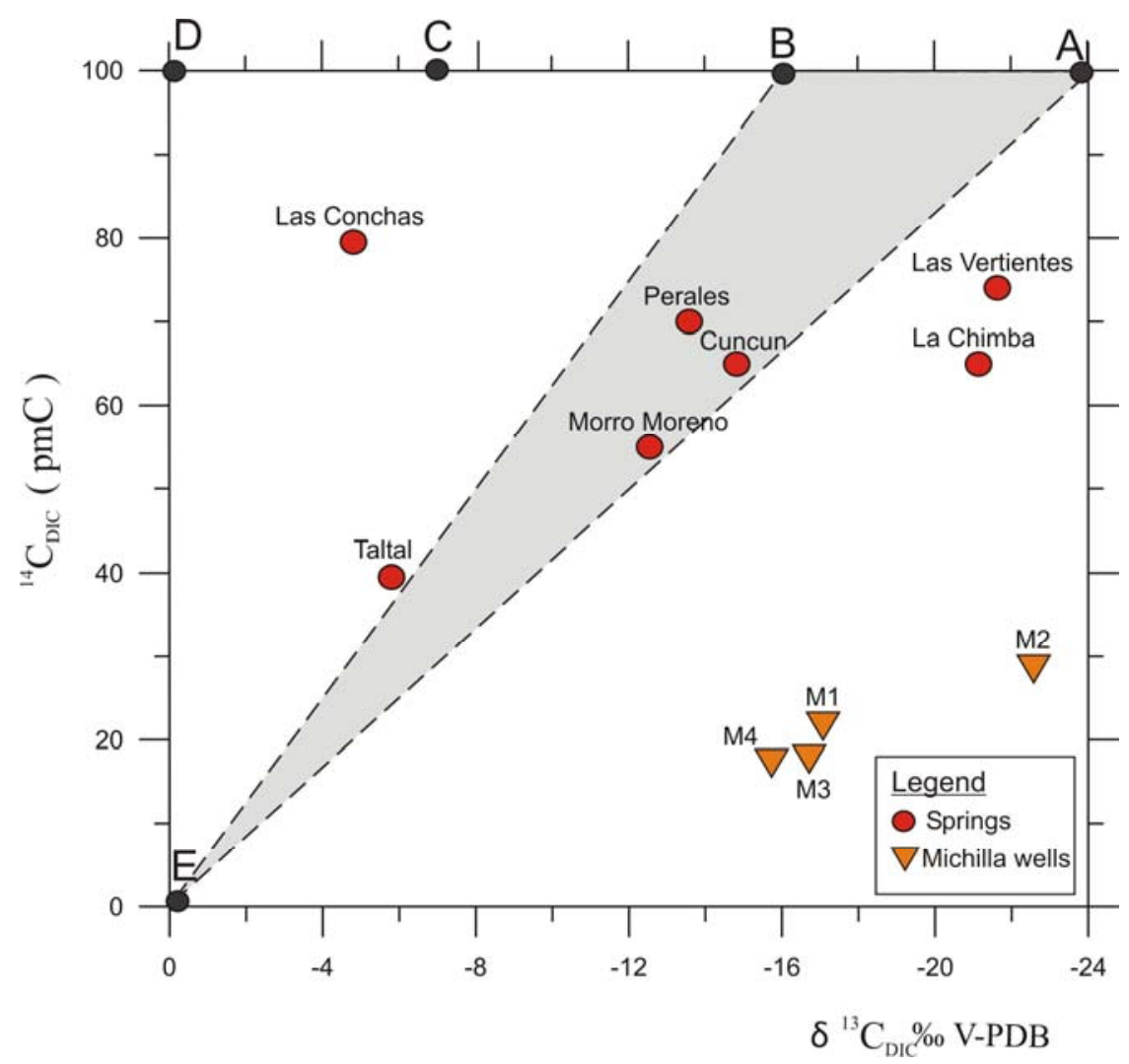

Fig. 12.- Plot of ${ }^{14} \mathrm{C}$ versus $\delta^{13} \mathrm{C} \%$ o(V-PDB) in the groundwater of Cordillera de la Costa to show the effect of mixtures of old marine carbonates and $\mathrm{HCO}_{3}$ in equilibrium with modern biogenic $\mathrm{CO}_{2}$. A. Modern biogenic $\mathrm{CO}_{2} ; \mathrm{B} . \mathrm{HCO}_{3}$ in equilibrium with modern biogenic $\mathrm{CO}_{2}$; C. Modern atmospheric $\mathrm{CO}_{2} ; \mathrm{D} . \mathrm{HCO}_{3}$ in isotopic equilibrium with $100 \mathrm{pmC}$ atmospheric $\mathrm{CO}_{2}$ and also modern marine carbonates; $\mathrm{E}$. Old marine carbonates. The water of Morro Moreno, Cuncun and Perales springs are located close to the mixture line between $\mathrm{HCO}_{3}$ in equilibrium with modern biogenic $\mathrm{CO}_{2}$ and old marine carbonates ( $\mathrm{EB}$ line) and close to the mixture line between the modern biogenic $\mathrm{CO}_{2}$ and the old marine carbonates (EA line). 